\title{
LEKTI, a physiological inhibitor of multiple serine proteinases, blocks migration and invasion of head and neck squamous cell carcinoma (HNSCC) cells
}

\begin{abstract}
Serine Protease Inhibitor Kazal-type 5 (SPINK5) gene encodes 3 different LymphoEpithelial Kazal-Type-Inhibitor (LEKTI) isoforms which are organized into longer than 15, 15, and 13 inhibitory domains. We identified LEKTI by its constitutive expression in normal oral mucosa and lost or down regulated expression in matched tumor specimens of patients with head and neck squamous cell carcinoma (HNSCC). Previously, we showed that recombinant full-length LEKTI and rLEKTI fragments inhibit the activity of plasmin, subtilisin A, cathepsin G, neutrophil elastase, trypsin, caspase 14, and kallikreins (KLK) 5, 6, 7, 13, and 14 to varied extents. Here, we show that LEKTI protein is absent in HNSCC OSC19, Tu138, Tu177, and UMSCC1 lines. We then determined the consequences of LEKTI re-expression on migration and invasion, adhesion and gene expression profile of HNSCCOSC19 and UMSCC1 lines. We demonstrate that LEKTI expressing OSC19 and UMSCC1 clones show markedly reduced migration and invasion. Moreover, LEKTI expressing OSC19 clones show striking morphological changes and enhanced adhesionon type I, III, IV, and V collagens, fibronectin, and laminin5.In addition, we show that exogenous r-LEKTI blocks migration of OSC19-parental cells in a dose and time dependent manner. Microarray analysis identified 186 genes which are differentially regulated in both OSC19 LEKTI clones.mMP-14, KLK5, and ADAM8 are down regulated whilemMP-3, LEKTI, DSC2 and DSC3are up-regulated in OSC19 LEKTI clones. RTPCR and Western blot results confirmed microarray results formMP-14 andmMP-3in OSC19 LEKTI clones. In addition we discover thatmMP-9 protein expression and pro-MMP-9 activity are severely reduced in LEKTI expressing clones as shown by WB and zymogram. Together, this work provides mechanistic insights into how loss of LEKTI protein expression promotes an invasive phenotype in HNSCC tumors.
\end{abstract}

Keywords: SPINK5, LEKTI, invasion, migration, adhesion, mMPs, HNSCC, KLK
Volume I Issue 3 - 2014

Arumugam Jayakumar, ${ }^{1,2}$ Chandrani Chattopadhyay,' Hua-Kang Wu,' Katrina Briggs, 'Ying Henderson,' 'Yaan Kang,' Latha Ramdas, ${ }^{3}$ Shikha Sharma, 'Venugopal Radjendirane, ${ }^{2}$ Thomas D Shellenberger,' Gary L Clayman'

'Department of Head and Neck Surgery, University of Texas MD Anderson Cancer Center, USA

2Department of Experimental Therapeutics, University of Texas MD Anderson Cancer Center, USA

${ }^{3}$ Department of Experimental Radiation Oncology, University of Texas MD Anderson Cancer Center, USA

Correspondence: Arumugam Jayakumar, Department of Head and Neck Surgery, University of Texas MD Anderson Cancer Center, Houston, Texas 77030, USA,

Email ajayakum@mdanderson.org

Received: July 01, 2014 | Published: July 08, 2014
Abbreviations: LEKTI, lympho-epithelial kazal-typeinhibitor; SPINK5, serine protease inhibitor kazal-type 5; KLK, kallikreins; kDa, kilodaltons; RT-PCR, reverse-transcriptase polymerase chain reaction; $\mathrm{SD}$, standard deviation of the mean

\section{Introduction}

Lympho-epithelial kazal-type-inhibitor (LEKTI)1 was named by one of the original groups who cloned this protein's gene to reflect the observed pattern of its expression in both epithelial tissue and leukocytes. ${ }^{1}$ It was later identified as the same gene as the defective gene in Netherton's syndrome, SPINK5 (serine protease inhibitor Kazaltype 5). ${ }^{2}$ Netherton's syndrome is a genetic disorder characterized by congenital ichthyosis, hair shaft abnormalities, immune deficiency, elevated immunoglobulin $\mathrm{E}$ ( $\mathrm{IgE}$ ) concentration, and failure to thrive. ${ }^{2-13}$ SPINK5 encodes the LEKTI protein which consists of 1064 amino acids organized into 15 potential inhibitory domains on the basis of the furin cleavage sites found within the full-length molecule. At the N-terminus is a secretory signal peptide sequence consisting of 22 amino acids. ${ }^{14}$ Two of the 15 LEKTI domains (domains 2 and 15) resemble typical Kazal-type serine proteinase inhibitors; the remaining 13 domains share partial homology to Kazal-type inhibitors but lack one of the three conserved Kazal-type disulfide bridges. ${ }^{15}$
We and others identified SPINK5 as one of the genes down regulated in head and neck squamous cell carcinoma (HNSCC). ${ }^{16,17}$ We cloned the cDNA encoding the $125-\mathrm{kDa}$ isoform and established that recombinant pro-LEKTI is a potent inhibitor of multiple serine proteinases implicated in metastasis and angiogenesis. Moreover, rLEKTI did not inhibit the cysteine proteinase papain or cathepsin $\mathrm{K}$, L, or S. We further showed that recombinant pro-LEKTI was very efficiently cleaved in vitro by furin into five major and thirteen minor proteolytic fragments. ${ }^{18}$ In the course of studies aimed at understanding the structure and function of some of these domains, we demonstrated that recombinant LEKTI6-9' inhibited trypsin and subtilisin A but not plasmin, cathepsin G, or elastase. ${ }^{19}$ We also produced a battery of LEKTI monoclonal antibodies and demonstrated that several of these LEKTI antibodies including 1C11G6 reacted specifically with proLEKTI, LEKTI domains 1-6, 6-9, 9-12, and 12-15. ${ }^{20}$ We demonstrated that the N-terminal signal peptide is required for LEKTI import into the ER and ordered the cleavage products on the $125 \mathrm{kDa}$ pro-LEKTI from the amino- to carboxy-terminal as follows: $37-, 40-$, and $60 \mathrm{kDa} .{ }^{21}$ In our subsequent work, we characterized the interaction of two recombinant LEKTI domains 6-8 and 9-12 with recombinant rhK5 and recombinant rhK $7 . .^{22}$ We showed that both fragments inhibited rhK5 similarly and established that LEKTI, at least in fragment form, is a potent inhibitor of $\mathrm{rhK} 5$ and that this protease may be a target of 
LEKTI in human skin. In our later studies we discovered that KLK5, KLK6, KLK13 and KLK14 were potently inhibited by rLEKTI (16), rLEKTI (6-9') and rLEKTI (9-12). ${ }^{23,24}$ We also assessed the basis for phenotypic variations in patients with "mild", "moderate" and "severe" NS. ${ }^{25}$ We observed that the magnitude of KLK activation correlated with both the barrier defect and clinical severity, and inversely with residual LEKTI expression and LEKTI co-localizes within the stratum corneum (SC) with kallikreins 5 and 7 and inhibits both KLKs. Recently, we demonstrated that caspase 14 is inhibited by full-length LEKTI and 5 recombinant fragments of LEKTI to varied extents. ${ }^{26}$

In the present study, we stably re-expressed LEKTI in HNSCC cells and evaluated the effects of LEKTI re-expression on cellular proliferation, morphology, adhesion, invasion and expression of key mMPs involved in tumor progression. LEKTI re-expression in OSC19 cells causes striking morphological changes, strongly enhances adhesion, markedly decreased migration and invasion. Stable re-expression of LEKTI in OSC19 cells resulted in markedly decreased levels of mMP-9 and mMP-14. Furthermore, these results demonstrate a novel negative regulatory role for LEKTI in modulating the production of keymMPs involved in ECM degradation and suggest that loss of LEKTI in HNSCC tumor cells could have a pivotal role in HNSCC progression.

\section{Materials and methods}

\section{Materials}

The following reagents were obtained commercially as indicated: Human embryonic kidney cells (HEK 293T) (American Type Culture Collection, Manassas, VA); primary normal epidermal keratinocytes (HNEKs) and keratinocyte growth medium (Cambrex Biosciences, Walkersville, MD); OSC-19 from Dr. There OPTIMEM (Life Technologies, Rockville, MD); precast sodium dodecyl sulfate (SDS)-polyacrylamide gels, prestained markers, gelatin Zymogram gels (Bio-Rad Laboratories, Hercules, CA); nitrocellulose membrane (Schleicher \& Schull BioScience, Keene, NH); YM3 Centriplus (Millipore, Bedford, MA); anti-LEKTI mAb1C11G6 (Zymed Laboratories, San Francisco, CA); collagens, I, III, and V, fibronectin, laminin-5, BSA, GAPDH, anti- $\beta$ actin, anti-MMP-9, and antiMMP-14 antibodies (Sigma-Aldrich, St. Louis, MO), horseradish peroxidase-conjugated goat-anti-mouse $\operatorname{IgG}(\mathrm{H}+\mathrm{L})$ (Jackson ImmunoResearch Laboratories, West Grove, PA); lipofectamine 2000 and pcDNA3.1 (-) (Invitrogen, Carlsbad, CA); ECL kit (Amersham Bioscience Corporation, Piscataway, NJ); Kodak X-AR5 films (Eastman Kodak, Rochester, NY); restriction endonucleases and polymerase chain reaction reagents (New England Biolabs, Beverely, MA); BD BioCoat Tumor Invasion System (BD Biosciences); r-LEKTI is purified in our laboratory as described previously. ${ }^{18}$

\section{Cell culture and transfections}

The HNSCC cell lines (Tu 138 and JMAR) were established at The University of Texas M. D. Anderson Cancer Center. Dr. Tom Carey at the University of Michigan developed UMSCC1. A human oral squamous cell carcinoma cell strain, OSC19, was obtained from Dr. Theresa Whiteside and maintained in Dulbecco's modified Eagle's medium (DMEM) supplemented with 10\% fetal bovine serum, $2 \mathrm{mM}$ glutamine, and antibiotics. HEK 293T were cultured in DMEM supplemented with $10 \%$ FBS and $2 \mathrm{mM}$ glutamine. HNEKs were cultured in keratinocyte growth medium containing low-calcium. All cells were cultured at $37^{\circ} \mathrm{C}$ in humidified incubator with $5 \% \mathrm{CO}_{2}$ and
$95 \%$ air. All cells were cultured at $37^{\circ} \mathrm{C}$ in humidified incubator with $5 \% \mathrm{CO}_{2}$ and $95 \%$ air.

To clone the pro-LEKTI expression plasmid, 3.24Kb BamHIKpnI fragment from LEKTI/pFASTBAC1, clone \#4 was sub cloned into pcDNA 3.1. The pro-LEKTI expression plasmid encodes the entire full-length LEKTI polypeptide and has a hexahistidine tag at its C-terminus. 293T cells transfected with this construct expressed LEKTI. At $24 \mathrm{~h}$ and $48 \mathrm{~h}$ post transfection, LEKTI is detected within the cells and in the medium. In the medium LEKTI processed LEKTI fragments are also detected with LEKTI mAb 1C11G6. In order to delete the signal sequence, this clone is digested with NotI and EcoRI and ligated to a PCR fragment lacking this signal sequence. The pro-LEKTI- $\Delta 1-22$ expression plasmid encodes the full-length LEKTI polypeptide without the $\mathrm{N}$-terminus secretory signal sequence and has a hexahistidine tag at its C-terminus. When transfected into $293 \mathrm{~T}$ cells, very little intracellular protein is observed. Following the verification of these expression clones, HNSCC cells were transfected with these constructs and stable clones were selected after G418 $(0.5 \mathrm{mg} / \mathrm{ml})$ selection. We also performed transient transfection of OSC-19 and HEK 293T cells with these constructs. Cells were plated in $60 \times 15-\mathrm{mm}$ tissue culture dishes grown to $70 \%$ confluence, and transiently transfected with $2.0 \mu \mathrm{g}$ each of pro-LEKTI expression plasmid DNA or pro-LEKTI- $\Delta 1-22$ expression plasmid DNA or control vector plasmid DNA using Lipofectamine 2000 according to the manufacturer's instructions. Approximately 50\% transfection efficiency was achieved as determined by transfection with a GFP control plasmid.

\section{LEKTI secretion assays}

Cells were washed twice in phosphate buffered saline (PBS) and resuspended in $4 \mathrm{ml}$ serum-free media for $24 \mathrm{hrs}$. The conditioned media was ten-fold concentrated by centrifugation using MilliporeYM3 Centriplus units (3,000 MWCO) and assayed for protein concentrations. ${ }^{27}$ To examine LEKTI expression in protein lysates, the adherent cells were trypsinized and solubilized in $100 \mu 1$ of icecold radio immunoprecipitation assay (RIPA) buffer containing 1\% Nonidet P-40, 1.0\% deoxycholate, $0.1 \%$ SDS, 50mM Tris- $\mathrm{HCl}$, $(\mathrm{pH}$ 7.5), $150 \mathrm{mM} \mathrm{NaCl}, 2 \mathrm{mM}$ EDTA and a mixture of protease inhibitors.

\section{Western blot}

Proteins or concentrated culture supernatants were mixed with $2 \times$ gel loading buffer (4\% SDS; $20 \%$ glycerol; $120 \mathrm{mM}$ Tris$\mathrm{HCl}, \mathrm{pH} 6.8 ; 0.01 \%$ bromophenol blue; with or without $10 \%$ $\beta$-mercaptoethanol), heated to $95^{\circ} \mathrm{C}$ for $5 \mathrm{~min}$, and resolved by SDS-PAGE $(10 \%$ gel). Electrophoretic transfer of proteins from the polyacrylamide gel onto a nitrocellulose membrane (Schleicher \& Schull BioScience, Inc., Keene, NH) was achieved by using aminitrans blot electrophoretic cell (Bio-Rad) at $25 \mathrm{~V}$ for $16 \mathrm{~h}$ at $4^{\circ} \mathrm{C}$. After blocking the nitrocellulose membrane overnight at room temperature with $3 \% \mathrm{BSA}$, it was incubated for $2 \mathrm{~h}$ at room temperature with primary and $1 \mathrm{~h}$ with the secondary antibody. The immunoblot was visualized using the chemiluminescence-ECL substrate and exposed to X-ray Hyperfilm MP for 1-3min.

\section{Adhesion assays}

The 96-well high binding non- tissue culture plates were coated with equimolar amounts of type I, III, IV, and V collagens, fibronectin, and laminin-5, and vitronectin $(100 \mathrm{nM})$ for $3-4$ hours at $37^{\circ} \mathrm{C}$. Control wells received BSA alone. Wells were blocked with 5\% BSA for 45 minutes prior to use. HNSCC cells are added at 2X104 cells/ 
well in serum-free DMEM. Cells were allowed to adhere at $37^{\circ} \mathrm{C}$ for 90 minutes. Following washing, remaining adherent cells were fixed with $0.5 \%$ crystal violet in methanol/water. Background binding was assessed using coated wells but received no cells and subtracted from experimental values. The crystal violet incorporated into cell were collected in $1 \%$ SDS and quantified by measuring $\mathrm{A}_{590}$.

\section{Migration and Invasion assays}

Cell migration and invasion was determined using BD BioCoat Tumor Invasion System that consists of a 24-Mutliwell-insert plate in which a PET membrane ( $8 \mu \mathrm{m}$ pore size) has been coated without or with Matrigel. OSC19-parent, OSC19-Vector-1, OSC19-LEKTI-11, and OSC19-LEKTI-17 clones suspended in medium without serum were added to the upper wells of inserts, which were then were placed into lower wells containing NIH 3T3 supernatant containing $10 \%$ fetal calf serum as a chemo attractant and allowed to invade for $24 \mathrm{~h}$ in a $\mathrm{CO}_{2}$ humidified incubator. To measure migration alone, parallel wells were set up with control inserts that lacked a Matrigel coating. Alternatively, OSC19-parent cells suspended in medium without serum and treated with recombinant pro-LEKTI were added to the upper wells of control inserts which were then were placed into lower wells containing NIH 3 T3 supernatant containing $10 \%$ fetal calf serum as a chemo attractant and allowed to migrate for $24 \mathrm{~h}$ in a $\mathrm{CO}_{2}$ humidified incubator. At the end of each assay, the lower sides of inserts containing migrated or invaded cells are stained and photographed.

\section{Gelatin zymography}

OSC19-parent, OSC19-Vector-1, OSC19-LEKTI-11, and OSC19LEKTI-17 clones grown in DMEM media containing 10\% fetal calf serum and $2 \mathrm{mM}$ glutamine were washed twice in phosphate buffered saline (PBS) and resuspended in $4 \mathrm{ml}$ of serum-free media for $24 \mathrm{hrs}$. Thereafter, $1 \mathrm{ml}$ of supernatants was collected, centrifuged (300xg) for $10 \mathrm{~min}$ to remove non-adherent cells and thereafter, supernatants were centrifuged a second time $(5000 \mathrm{xg})$ for $10 \mathrm{~min}$ to remove cell debris and nuclei. Supernatants were concentrated (10X) by centrifugation using Millipore-YM3 Centriplus units (3,000 MWCO). $5 \mu 1$ concentrated supernatants are mixed with Zymogram sample buffer in the absence of reducing agents and electrophoresed through $12 \%$ polyacrylamidegels containing $0.1 \%(\mathrm{w} / \mathrm{v})$. Electrophoresis was carried out at $125 \mathrm{~V}$. After electrophoresis, the gel was washed twice with $100 \mathrm{ml}$ of $2.5 \%(\mathrm{v} / \mathrm{v})$ Triton $\mathrm{X}-100$ at $22^{\circ} \mathrm{C}$ for $30 \mathrm{~min}$ to remove SDS, and three times for $10 \mathrm{~min}$ with $\mathrm{H}_{2} \mathrm{O}$ to remove Triton $\mathrm{X}-100$. The gel was incubated in $50 \mathrm{mM}$ Tris- $\mathrm{HCl}, 0.2 \mathrm{M} \mathrm{NaCl}, 20 \mathrm{mM} \mathrm{CaCl}_{2}$, $\mathrm{pH} 7.4$ at $37 \mathrm{C}$ for $12 \mathrm{~h}$, stained over night with Coomassie Brilliant Blue R-250 0.5\% (w/v) in 45\% (v/v) methanol-10\% (v/v) acetic acid and destained in the same solution without dye. The location of gelatinolytic activity is visualized as a clear band on the uniformly stained background.

\section{Northern blot and Real time PCR}

Total RNA isolation, Northern blot and Real-time PCR were performed as described earlier. ${ }^{28}$ Total RNA was prepared using TriZol reagent (Invitrogen) according to the manufacturer's instructions. For Northern blot, $20 \mu \mathrm{g}$ total RNA was applied to a $1 \%$ formaldehyde agarose gel. After transferring RNA to Hybond$\mathrm{Np}$ membrane (Amersham), the membrane and the filter were hybridized with ${ }^{32} \mathrm{P}-\mathrm{r}-$ human LEKTI or ${ }^{32} \mathrm{P}-\mathrm{GAPDH}$. For Real-time PCR, $2 \mu \mathrm{g}$ total RNA were reverse transcribed (RT) by Superscript II (Life Technologies) in a $25 \mu$ l total reaction volume containing RT buffer, random hexamers, dNTP, and RNase inhibitor (Roche Applied Science, Indianapolis, IN). Real-time PCR was performed in a $25 \mu \mathrm{l}$ total reaction volume containing $1 \mu$ of 1:10 diluted cDNA obtained from RT reaction, $12.5 \mu \mathrm{l}$ of TaqMan Universal PCR Master Mix without AmpErase UNG, and $1.25 \mu$ of specific primers for each gene on ABI Prism 7900HT (kindly provided by Dr. Adel El-Naggar from the Department of Pathology, M. D. Anderson Cancer Center). As a control, 18S primers were used, and cDNA was diluted to 1:500. Serial dilutions of the standard templates were also used for parallel amplifications. The threshold cycles $(\mathrm{Ct})$ were calculated with $\mathrm{ABI}$ Prism 7900HT SDS software (Applied Biosystems). The quantities of samples were determined from the standard curves. Levels ofmMP-3, mMP-9 andmMP-19 mRNA were normalized to those of $18 \mathrm{~S}$ in each sample. For statistical analysis, the Tukey HSD analysis of variance post hoc test was used as a univariate test for significant differences between the ratio means and the $\mathrm{P}$ value was determined. A P value of 0.05 or less was considered significant.

\section{Microarray analysis}

Total cellular RNA isolation, cDNA preparation, and microarray analysis were performed as described previously. ${ }^{28,29}$ Briefly, hybridization to microarrays was performed using human oligonucleotide-spotted glass array with 18,861 60-mer oligos and controls produced in the Wiegand Radiation Oncology Microarray Core Facility at our institution. Hybridization was carried out for $16 \mathrm{~h}$ at $50^{\circ} \mathrm{C}$. Scanned images were quantified in Array Vision (Imaging Research, Inc., St. Catherine's, Ontario, Canada). Measurements were recorded for spot intensity, local background intensity, and signal-to-noise ratio. Spot intensity was computed as the integrated absorbance or volume in a fixed-size circle. Background intensity was computed as the median pixel value in four diamond-shaped regions at the corners of each spot. The signal-to-noise ratio was computed by dividing the background-corrected intensity by the SD of the background pixels. Quantified array data were imported into S-Plus software (Insightful Corp., Seattle, WA) for analysis. Backgroundcorrected intensities were globally rescaled to set the 75 th percentile in each channel equal to 1,024 . Rescaled intensities of $<128$ were replaced by the threshold value; this threshold was chosen to lie just below the smallest intensity of any spot with a signal-to-noise ratio $>1$. Next, intensities were transformed by computing the base 2 logarithm. Finally, the log-transformed spot intensities were normalized using robust local regression. A spot was identified as differentially expressed if the mean intensity in the two channels exceeded 512 and the estimated change exceeded 2.5 -fold or if the mean intensity in the two channels exceeded 256 and the estimated change exceeded 4.5 -fold. The normalized data was logarithm transformed to base 2 and the mean data of the replicates was determined. The log ratio values were calculated for the clones 11 and 17 and corresponding paired vector controls. Differentially regulated mRNA between the 2 samples was identified using a paired $t$ test. We included the complete microarray dataset as a supplementary Microsoft Excel file and also in the process of depositing our dataset to Array Express database soon.

\section{Results and discussion}

\section{Analysis of LEKTI mRNA and LEKTI protein expression in HNSCC tumor lines}

Using Northern blotting, we analyzed the expression of LEKTI mRNA in HNEK, HEK 293T-vector transfect ant, HEK 293T-LEKTI transfect ant, and HNSCC OSC19, Tu138 and Tu177 tumor lines. Northern blot analysis showed that a 3.75-kb mRNA band was detected 
in HNEK and 293T cells transiently transfected with pro-LEKTI expression plasmid. This transcript is not detectable in 293T-vector transfectant and OSC19 cells but present in reduced levels in Tu177 and Tu138 cell lines. The results were consistent with the patterns of LEKTI mRNA expression previously reported for normal oral epithelium and several HNSCC cell lines including Tu138 and Tu 177 (Figure 1A). ${ }^{16}$ Using Western blotting, we analyzed the expression of native LEKTI protein by using anti-LEKTI mAb 1C11G6 and protein lysates from HNEK, HEK 293T-vector transfectant, and HNSCC OSC19, Tu138, Tu177, and UMSCC1 tumor lines. Anti-LEKTI antibody $1 \mathrm{C} 11 \mathrm{G} 6$ recognized a major protein of $\sim 125 \mathrm{kDa}$ and amine or protein of $110 \mathrm{kDa}$ in HNEKs indicating robust expression of LEKTI protein; in contrast both bands were absent in all four HNSCC tumor lines (Figure 1B). The endogenously expressed $125 \mathrm{kDa}$ LEKTI found in HNEKs was identical to r-pro-LEKTI expressed and purified from insect cells. ${ }^{18}$ Protein lysates from HEK $293 \mathrm{~T}$ cell transfected with control vector showed no endogenous LEKTI expression. This Western blot signal was completely absent when a preserum was used. The results were consistent with the patterns of LEKTI protein expression reported for normal kidney and colon tissues. ${ }^{30}$

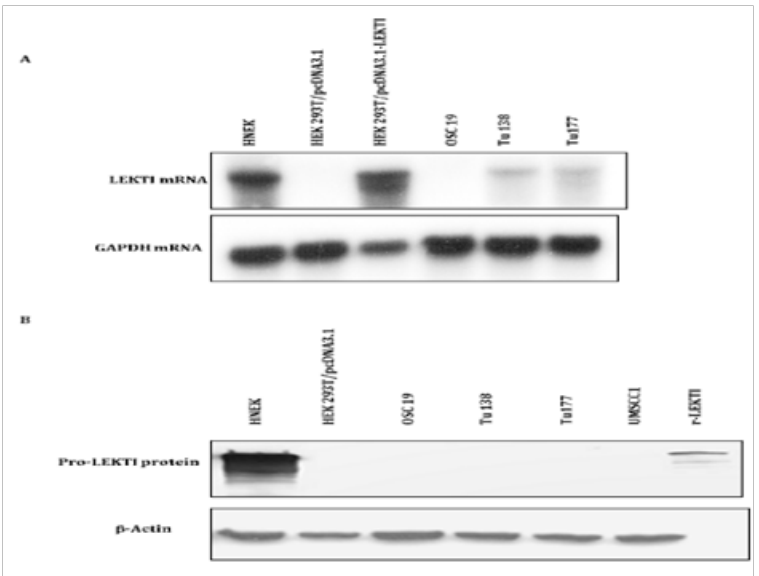

Figure I LEKTI is absent from the established HNSCC lines.A: LEKTI mRNA in HNEK, 293T-vector transfectant, 293T-LEKTI tranfectant, and HNSCC tumor lines. Northern blot analysis showed that a $3.75-\mathrm{kb}$ mRNA band was detected in HNEK and 293T-LEKTI transfectant. This transcript is not detectable in 293T-vectortransfectant and OSCI9cells but present in reduced levels in Tul77 and Tul 38 cell lines. B: LEKTI protein expression in HNEK, 293T-vector transfectant, and HNSCC tumor lines. Western blot analysis with the anti-LEKTI mAbICIIG6 showed the $125 \mathrm{kDa}$ native pro-LEKTI protein in $50 \mu \mathrm{g}$ cell lysates of HNEK cells. This band is not detectable in 293T-vector transfectant, OSCI9, Tu 177,Tu 138, and UMSCCI cell lines. r-LEKTI detection serves as a positive control. Actin detection allows the comparison between samples loading. Results are representative of three independent experiments using cultures from three different transfections.

\section{Stable LEKTI re-expression inhibits matrigel migration and invasion of OSC19}

To understand the impact of LEKTI re-expression in HNSCC cells, we cloned a native LEKTI cDNA fragment encoding proLEKTI protein into the expression vector pcDNA3.1, transfected into OSC19 and UMSCC1 cells and isolated several stable clones after $\mathrm{G} 418(0.5 \mathrm{mg} / \mathrm{ml})$ selection for almost a month. We selected one OSC19-vector clone 1; two OSC19-LEKTI clones 11 and 17 and one UMSCC1 clone 2 for further studies. We examined the cell lysates and conditioned medium from these clones for the expression of recombinant and for the presence of processed LEKTI fragments by Western blot assays (Figure 2A). Stable expression of recombinant LEKTI in these three clones is processed and secreted into the medium similar to what we reported for HNEK cells. ${ }^{21}$ We recently showed that native pro-LEKTI in HNEK cells is processed and secreted into the medium by an ER/Golgi-dependent pathway. Furthermore, we demonstrated that endogenous furin plays a pivotal role in the processing pro-LEKTI. Now, we show that stably expressed recombinant LEKTI in OSC19 and UMSCC1cells is also similarly processed and secreted into the medium.

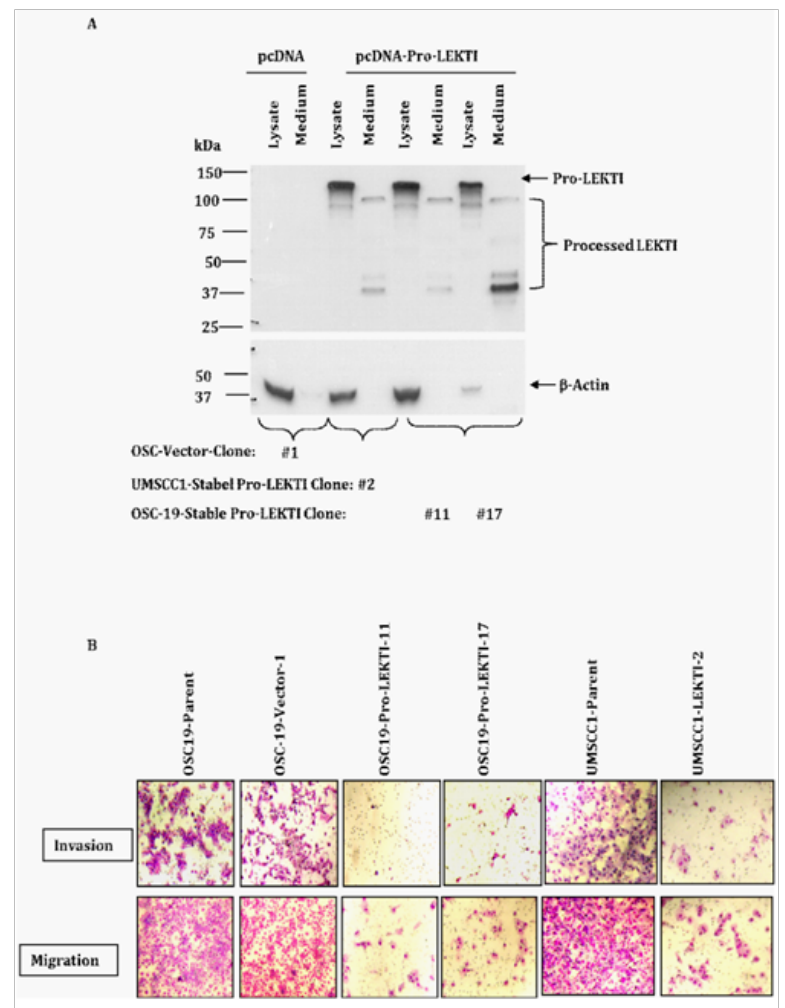

Figure 2 Stable LEKTI re-expression inhibits matrigel migration and invasion of OSCI9 and UMSCCI. A: LEKTI protein in cell lysate and medium of OSC 19-Vector clone I, OSC 19-LEKTI clones II and I7 and UMSCC-LEKTI clone 2. Western blot analysisshowed the $125 \mathrm{kDa}$ native pro-LEKTI protein in cell lysates and about 37-, 40-, and 60 (very faint) kDa processed LEKTI fragments in the medium of OSCI9-LEKTI clones II and 17 and UMSCCLEKTI clone 2 (The $100 \mathrm{kDa}$ band represents intermediate cleavage product of LEKTI). These bands are not detectable in OSCI9-Vector clone I. Actin detection allows the comparison between samples loading. B: Stable LEKTI expression results in inhibition of migration and invasion of HNSCC tumor lines OSCI 9 and UMSCCI in vitro.

In our pilot studies we noticed no migration of any of our HNSCC lines in conditions in which no chemo attractant was added. Hence, we compared the chemotactic migration of various HNSCC tumor lines in response to 5\% FCS or NIH3T3 supernatant in an uncoated control insert plate with a PET membrane containing 8micron pores. We found that NIH $3 \mathrm{~T} 3$ supernatant proved a more optimal chemo attractant with a $30 \%$ increase in cell migration compared to $5 \%$ FBS. In addition, we observed a 2 - to 3.5 -fold increase in the migration of OSC19 compared with UMSCC1. On the basis of these results, we used the NIH 3 T3 supernatant as a chemo attractant in our subsequent assays. In each of two LEKTI expressing clones of OSC-19, invasion was dramatically reduced compared to parental and vector cells (Figure 2B). Likewise, in LEKTI expressing clones of UMSCC2 invasion were significantly reduced compared to parental cells. We found more number of OSC19 parental and vector cells and 
UMSCC1 parental cells stained under migration than under invasion assays. Surprisingly, in each of two LEKTI expressing clones of OSC19 and one LEKTI expressing clones of UMSCC1, migration also was dramatically reduced compared to parental and vector cells. On the basis of these results, we conclude that LEKTI in tumor cells most likely functions in the extracellular tumor microenvironment and furthermore the levels of LEKTI in LEKTI transfected HNSCC cell model are comparable with those existing naturally. These data suggest that stable LEKTI expression results in inhibition of migration and invasion of HNSCC tumor lines in vitro.

\section{Transient LEKTI re-expression inhibits matrigel migration of OSC 19}

To determine the effect of LEKTI re-expression on cellular migration, we transiently transfected OSC19 cells with pro-LEKTI or pro-LEKTI deleted for the N-terminal secretory sequence. Using these transfectants we first characterized LEKTI expression and then performed migration assays. We observed that the expression of carboxy-terminal hexa-histidine tagged pro-LEKTI with it signal sequence and its processed LEKTI fragments was abundant in the cell lysates and supernatant as shown by its immuno reactivity with LEKTI $\mathrm{mAb}$ (Figure $3 \mathrm{~A}$ ). In contrast, deletion of the signal peptide resulted in markedly low levels of pro-LEKTI- $\Delta 1-22$ in the soluble fraction of cell lysates (Figure 3A), and we could not detect any processed LEKTI fragments in the conditioned medium (Figure 3A). These results are in agreement with our previous studies where we demonstrated that pro-LEKTI is processed and secreted into the medium in HEK 293T cells transiently transfected with the pro-LEKTI expression plasmid whereas the level of pro-LEKTI- $\Delta 1-22$ in lysates and medium went down dramatically. ${ }^{21}$

The migration of OSC19 cells transfected with empty vector was comparable to their un-transfected OSC19 parental cells (Figure 3B). In contrast, the migration of OSC19 Pro-LEKTI transfectent through Matrigel was inhibited by more than $95 \%(\mathrm{P}=0.001)$. On the other hand, the migration of pro-LEKTI- $\Delta 1-22$ transfectant through Matrigel was not affected and it is comparable to OSC19 cells transfected with empty vector and un-transfected OSC19 parental cells. On the basis of these results we conclude that LEKTI protein is directly responsible for the inhibition of OSC19 migration and also functional LEKTI is required to exert its inhibitory effect on migration.

\section{Exogenous r-LEKTI inhibits matrigel invasion and migration of OSC 19}

Next, we tested if exogenous r-LEKTI can elicit the inhibition of migration of OSC parental cells. Recombinant pro-LEKTI was expressed and purified from insect cells as described previously. ${ }^{18,23,31}$ OSC19 parental cells are treated without r-LEKTI or with $10 \mathrm{nM}$, $30 \mathrm{nM}$, and $100 \mathrm{nM} \mathrm{r}$-LEKTI for $24 \mathrm{~h}$ or with $30 \mathrm{nM}$ r-LEKTI for $0 \mathrm{~h}$, $6 \mathrm{~h}, 18 \mathrm{~h}$, and $24 \mathrm{~h}$ and then cells were allowed to migrate for $24 \mathrm{~h}$ with control inserts that lacked a Matrigel coating in a $\mathrm{CO}_{2}$ humidified incubator. Migration assays show that r-LEKTI inhibits the migration of OSC19 cells in a dose and time dependent fashion (Figure 4). No inhibition of migration was observed after $6 \mathrm{~h}$ incubation with $30 \mathrm{nM}$ $\mathrm{r}$-LEKTI but $18 \mathrm{~h}$ incubation resulted in substantial inhibition and $24 \mathrm{~h}$ incubation showed almost a total inhibition.

\section{LEKTI re-expression enhances adhesion and regulates the morphology of OSCI9}

We observed that both OSC19 LEKTI clones required more time for trypsinization when passaging the cells. To test this observation and determine the adhesion of cells to extracellular matrix constituents in relation to LEKTI expression, we performed assays of OSC19 cell adhesion to collagen type I, collagen type III, collagen type IV, collagen type V, laminin-5, fibronectin, and vitronectin. After $3 \mathrm{~h}$ of adhesion, each of two LEKTI-expressing clones demonstrated increased adhesion to collagen I, III, IV, IV, laminin-5, and fibronectin compared to parental and vector cells (Figure 5A). The increase in adhesion of OSC19-LEKTI clones to collagen I, III, IV, IV, laminin-5, and fibronectin was $1300,100,150,200,300$ and $40 \%$ respectively. In contrast, when plated on vitronectin, both control and LEKTI stable clones showed a similar extent of adhesion. Additionally, the morphology of LEKTI-expressing OSC19 clones was drastically altered from the parental and vector cells. After 4days of culture in normal tissue culture plates, the parental and vector cells formed thin and spreading stellate shapes with numerous processes (Figure 5B). In contrast, each of two LEKTI-expressing clones of OSC19 formed polygonal shapes and aggregated into compacts clumps. On the basis of these results, we conclude that re-expressed LEKTI in HNSCC cells lead to a cell type specific increase in adhesion onto specific extracellular matrix substrates. These observations suggest that LEKTI expression regulates cell morphology to result in a more differentiated phenotype resembling the architecture of squamous epithelium.

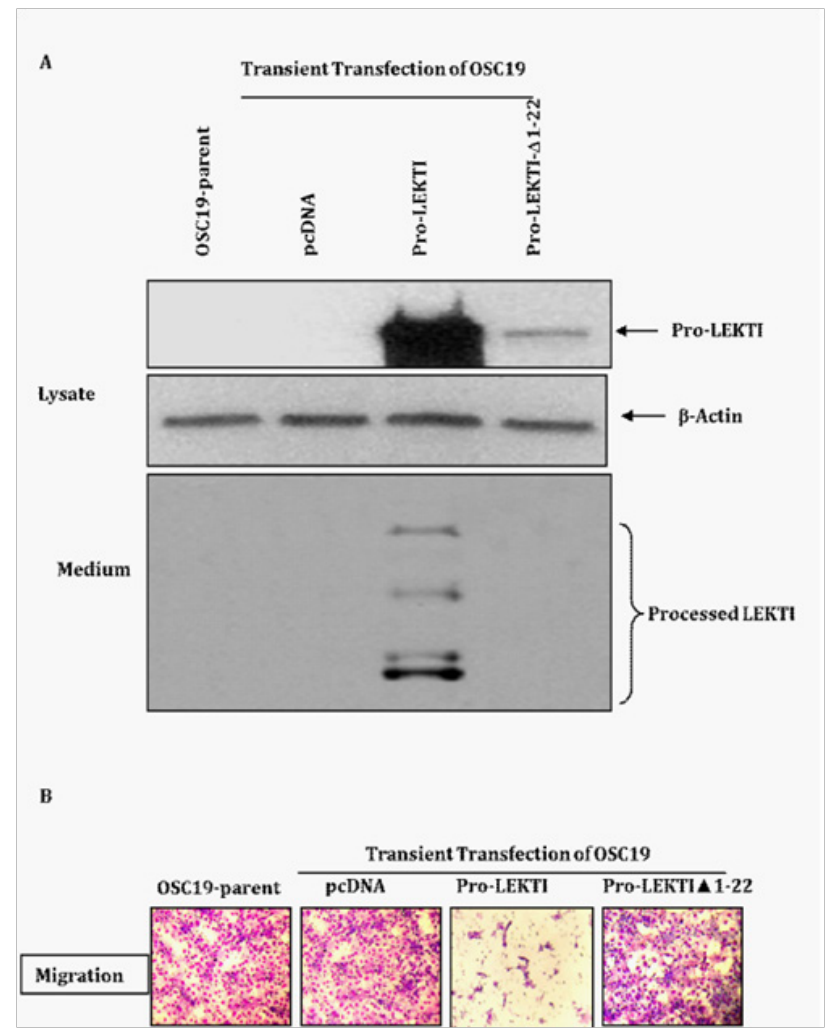

Figure 3 Transient LEKTI re-expression inhibits matrigel migration of OSCI9. A: LEKTI protein expression in OSCI9 cells transiently transfected with vector DNA or pro-LEKTI or pro-LEKTI- $\triangle \mathrm{I}$-22expression plasmid DNA. Western blot analysis showed the $125 \mathrm{kDa}$ native pro-LEKTI protein in lysates and about 37-, 40-, and $60 \mathrm{kDa}$ processed LEKTI fragments in the medium of OSC19 (the $100 \mathrm{kDa}$ band represents intermediate cleavage product of LEKTI). These bands are not detectable in OSCI9-Vector transfectant and a very faint band is visible in OSCI9-pro-LEKTI- $\Delta \mathrm{I}-22$ expression plasmid DNA. Actin detection allows the comparison between samples loading. B: Migration of OSCI9 cells transiently transfected with vector DNA or proLEKTI or pro-LEKTI- $\Delta$ I-22expression plasmid DNA.The migration of OSC 19 cells transfected with empty vector was comparable to their parental line OSC 19. The migration of OSC 19 pro-LEKTI but not OSCI9-pro-LEKTI- $\Delta$ I22through Matrigel was inhibited by more than $90 \%(P=0.00 I)$.Results are representative of three independent experiments using cultures from three different transfections. 


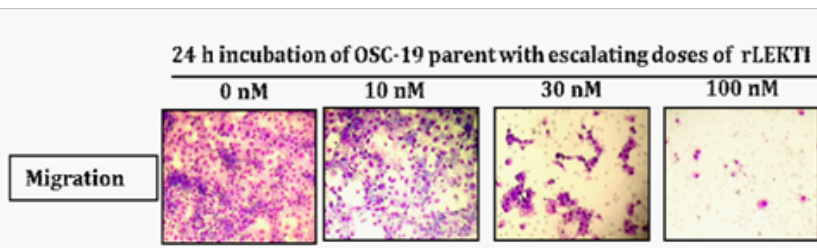

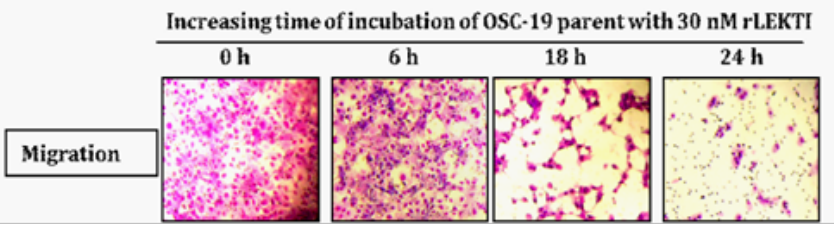

Figure 4 Exogenous r-LEKTI inhibits matrigel invasion and migration of OSC 19. Migration of OSC-Parent. OSCI9 parent cells are treated without r-LEKTI or with I0nM, 30nM, and I00nM r-LEKTI for 24h or with $30 \mathrm{nM}$ r-LEKTI for $0 \mathrm{~h}, 6 \mathrm{~h}, 18 \mathrm{~h}$, and $24 \mathrm{~h}$ and then cells were allowed to invade for $24 \mathrm{~h}$ with control inserts that lacked a Matrigel coating in a $\mathrm{CO}_{2}$ humidified incubator. Migration assays show that r-LEKTI inhibits the migration of OSCI9 cells in a dose and time dependent fashion. Results are representative of three independent experiments using r-LEKTI from three different purifications.

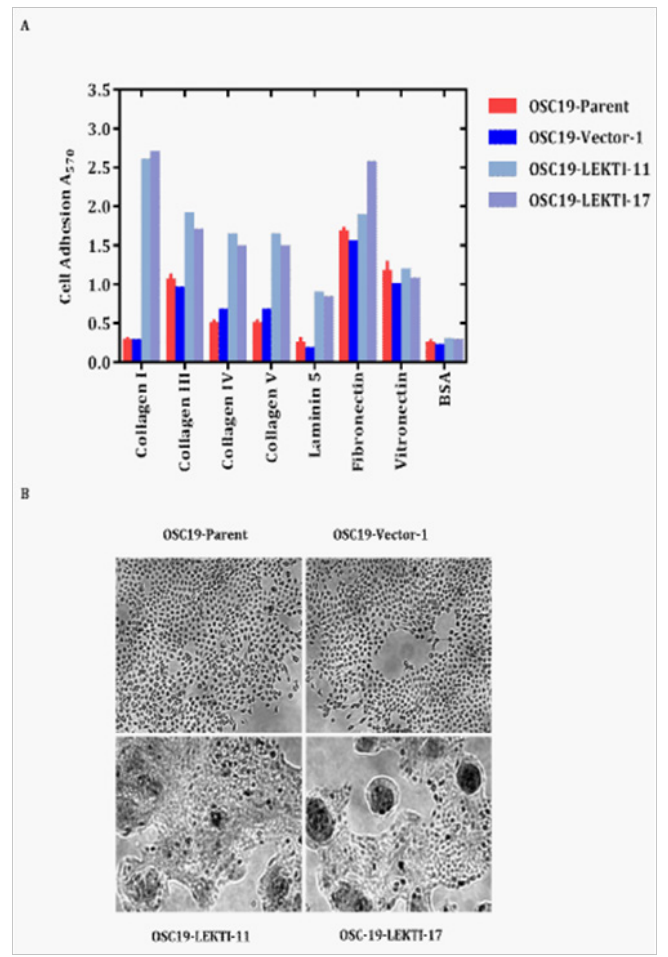

Figure 5 LEKTI re-expression enhances adhesion and regulates the morphology of OSC19. A: Adhesion of OSC-Parent, OSCI9-Vector clone I, OSCI9-LEKTI clones II and I7 on type I, III, IV, and V collagens, laminin-5, fibronectin, vitronectin, and BSA. Each of the two LEKTI-expressing clones demonstrated significantly increased adhesion $(\mathrm{P}<0.005)$ to collagen I, III, IV,V, and laminin-5, compared to parental and vector cells. The percentage increase in adhesion of OSCI 9-LEKTI cells to collagen I, III, IV,V, and laminin-5, was I 300, $100,150,150$, and $300 \%$, respectively. In contrast, when plated on vitronectin, fibronectin, or BSA, both control and LEKTI stable clones showed a similar extent of adhesion. B: Photographs of OSC-Parent, OSC-Vector-I, and OSC19-LEKTI clones II and 17. After 4 days of culture in normal tissue culture plates, the parental and vector cells formed thin and spreading stellate shapes with numerous processes. In contrast, each of two LEKTI-expressing clones of OSCI9 formed polygonal shapes and aggregated into compacts clumps. Results are representative of two independent experiments using cultures from two different platings.

\section{LEKTI re-expression negatively regulates expression ofmMP-9 and - 14}

Microarray analysis identified 186 genes which are differentially regulated between LEKTI clones in comparison with the vector transfected OSC19. Among them,mMP-14,mMP-8, KLK5, and ADAM8 are down regulated andmMP-3, LEKTI, DSC2 and DSC3 are up-regulated in LEKTI clones (Table 1) of the four classes of proteolytic enzymes, which include mMPs, serine proteinases, cysteine proteinases, and aspartate proteinases, them MPs are most important to the process of metastasis. ${ }^{32,33}$ To examine the expression of mMPs in relation to LEKTI expression we performed analysis of mMPs in OSC19 parental, vector, and LEKTI- expressing clones 11 and 17. By real-time PCR, each LEKTI-expressing clone showed a decrease in mMP-14 and an increase inmMP-3 transcript (Figure 6A). These results confirmed our microarray results on these two mMPs (Table 2). In addition, we found out that each LEKTI-expressing clone showed a decrease inmMP-9 mRNA expression relative to parental and vector cells (Figure 6A). Consistent with down regulation ofmMP-9 and mMP-14 mRNA expression, each LEKTI-expressing clone showed dramatic reduction in mMP-9 and -14-protein level relative to parental and vector cells (Figure 6B). We confirmed this finding by zymogram showing a decrease in $\mathrm{mMP}-9$ protein activity levels in response to LEKTI expression (Figure 6B).

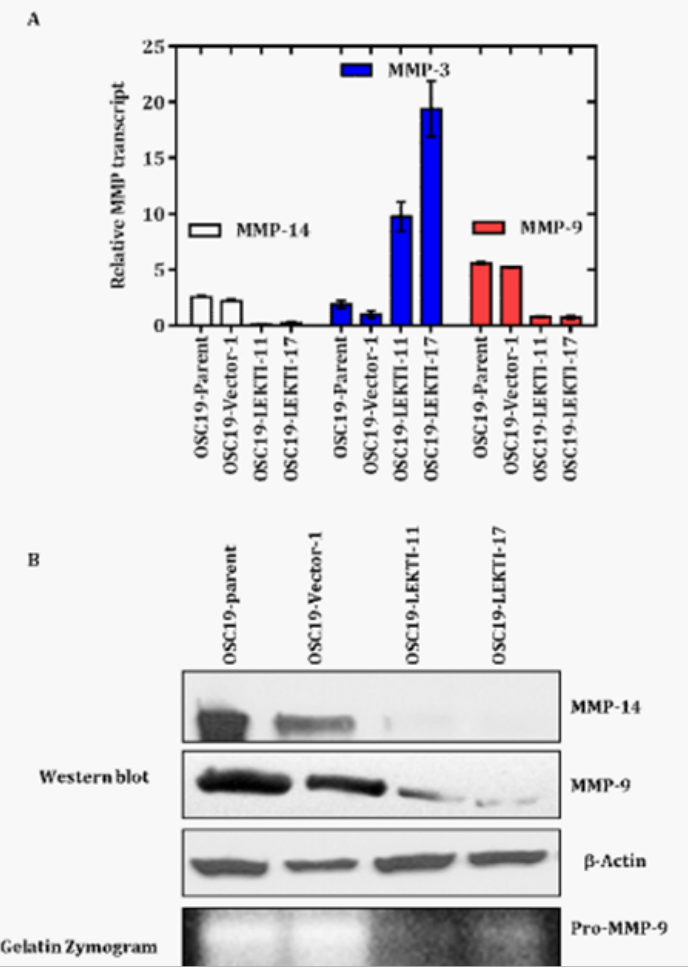

Figure 6 LEKTI re-expression negatively regulates expression of MMP-9 and - 14. A: Relative level of MMP- I4, MMP-9 and MMP-3 transcriptin OSC-Parent, OSCI9-Vector clone I, OSCI9-LEKTI clones II and I7 as determined by RT-PCR. MMP- 14 and MMP-9 transcripts went down while MMP-3 transcript went up in both clones. B: MMP-9 and MMP-14 protein expression in OSCParent, OSCI9-Vector clone I, OSC I9-LEKTI clones II and I7. Western blot analysis with the anti- MMP-9 and anti-MMP-14 showed the MMP-9 and MMP-

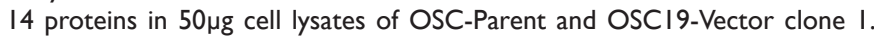
These bands are present markedly reduced levels in OSCI9-LEKTI clones II and 17. Actin detection allows the comparison between samples loading. Gelatin zymogram shows pro-MMP-9 activity in OSC-Parent and OSC19Vector clone I and markedly reduced pro-MMP-9 activity in OSCI9-LEKTI clones II and 17. Results are representative of three independent experiments using cultures from three different platings. 
Table I L4_S0335 and L4_S0337: Common genes that are differentially regulated between Clone II and CloneI7 in comparison with the vector transfected OSC-19. The positive logratio values are for genes that are upregulated in the clones and the negative logratio values are genes downregulated in the clones

\begin{tabular}{|c|c|c|c|c|c|c|c|c|c|}
\hline \multirow{2}{*}{$\begin{array}{l}\text { Spot } \\
\text { Location }\end{array}$} & \multirow[b]{2}{*}{ UGRepAcc } & \multirow[b]{2}{*}{ Symbol } & \multirow[b]{2}{*}{ Name } & \multirow{2}{*}{$\begin{array}{l}\text { Clone } \\
\text { I I_log } \\
\text { ratio }\end{array}$} & \multirow{2}{*}{$\begin{array}{l}\text { Clone } \\
17 \_l o g \\
\text { ratio }\end{array}$} & \multicolumn{2}{|l|}{ Up regulation } & \multicolumn{2}{|c|}{ Down regulation } \\
\hline & & & & & & $\begin{array}{l}\text { Foldchange } \\
\text { clonel I }\end{array}$ & $\begin{array}{l}\text { Foldchange } \\
\text { clone } 17\end{array}$ & $\begin{array}{l}\text { Foldchange } \\
\text { clone II }\end{array}$ & $\begin{array}{l}\text { Foldchange } \\
\text { clone } 17\end{array}$ \\
\hline C-6:23-8 & NM_0015I2 & GSTA4 & glutathione S-transferase A4 & 15.86 & 14.37 & 59575.04 & 21128.97 & & \\
\hline A-8:|2-II & NM_002373 & MAPIA & $\begin{array}{l}\text { microtubule-associated } \\
\text { protein IA }\end{array}$ & 15.86 & 14.99 & 59300.62 & 32530.79 & & \\
\hline B-3:17-5 & NM_006536 & CLCA2 & $\begin{array}{l}\text { chloride channel, calcium } \\
\text { activated, family member } 2\end{array}$ & 14.95 & 2.02 & 31659.09 & 4.04 & & \\
\hline D-7:16-2 & AL050367 & LOC22I06I & $\begin{array}{l}\text { hypothetical protein } \\
\text { LOC221061 }\end{array}$ & 14.30 & 14.73 & 20215.06 & 27092.83 & & \\
\hline B-2:6-14 & NM_0I8372 & RIFI & receptor-interacting factor I & 14.15 & 4.94 & 18239.04 & 30.70 & & \\
\hline A-8:4-3 & XM_290809 & TAF4B & $\begin{array}{l}\text { TAF4b RNA polymerase II, } \\
\text { TATA box binding protein } \\
\text { (TBP)-associated factor, } \\
\text { 105kDa }\end{array}$ & 13.92 & 15.21 & 15523.79 & 37944.50 & & \\
\hline$B-6: 1-23$ & NM_006I80 & NTRK2 & $\begin{array}{l}\text { neurotrophic tyrosine kinase, } \\
\text { receptor, type } 2\end{array}$ & 13.87 & 4.72 & 14952.63 & 26.31 & & \\
\hline A-5:16-I & NM_025247 & ALDH2 & $\begin{array}{l}\text { aldehyde dehydrogenase } 2 \\
\text { family (mitochondrial) }\end{array}$ & 13.45 & 3.30 & 11189.55 & 9.84 & & \\
\hline A-6:20-14 & NM_00I449 & $\mathrm{FHLI}$ & four and a half LIM domains I & 13.34 & 14.21 & 10337.80 & $|8959.5|$ & & \\
\hline C-7:24-I & NM_00069I & ALDH3AI & $\begin{array}{l}\text { aldehyde dehydrogenase } 3 \\
\text { family, memberAI }\end{array}$ & 9.53 & 6.70 & 737.55 & 103.98 & & \\
\hline D-2:12-5 & NM_00242I & MMPI & $\begin{array}{l}\text { matrix metalloproteinase I } \\
\text { (interstitial collagenase) }\end{array}$ & 8.14 & 14.06 & 281.19 & $17059.2 \mid$ & & \\
\hline A-1:2-10 & NM_002638 & $\mathrm{PI} 3$ & $\begin{array}{l}\text { protease inhibitor 3, skin- } \\
\text { derived (SKALP) }\end{array}$ & 7.84 & 3.57 & 229.76 & 11.84 & & \\
\hline$B-2: 13-12$ & NM_002964 & SI00A8 & $\begin{array}{l}\text { SI00 calcium binding protein } \\
\text { A8 (calgranulin A) }\end{array}$ & 6.32 & 5.85 & 79.70 & 57.61 & & \\
\hline D-3:7-14 & NM_00456I & OVOLI & ovo-like I(Drosophila) & 6.10 & 3.79 & 68.59 & 13.83 & & \\
\hline$C-4: 25-15$ & NM_006783 & GJB6 & $\begin{array}{l}\text { gap junction protein, beta } 6 \\
\text { (connexin 30) }\end{array}$ & 6.07 & 14.86 & 67.11 & 29790.05 & & \\
\hline A-8:24- 15 & NM_0I4220 & TM4SFI & $\begin{array}{l}\text { transmembrane } 4 \text { superfamily } \\
\text { member I }\end{array}$ & 5.53 & 5.90 & 46.05 & 59.70 & & \\
\hline D-5:17-6 & NM_006227 & PLTP & phospholipid transfer protein & 5.38 & 5.30 & 41.55 & 39.44 & & \\
\hline C-2:4-1I & NM_002272 & KRT4 & keratin 4 & 5.37 & 2.57 & 41.47 & 5.92 & & \\
\hline B-2:II-I & NM_005329 & HAS3 & hyaluronan synthase 3 & 5.34 & 4.21 & 40.39 & 18.45 & & \\
\hline A-3:25-9 & NM_153490 & KRTI3 & keratin 13 & 5.32 & 3.73 & 40.06 & 13.27 & & \\
\hline B-I:I5-I & NM_022746 & FLJ22390 & hypothetical protein FLJ22390 & 5.29 & 2.64 & 39.20 & 6.24 & & \\
\hline$D-3: 8-6$ & NM_00I353 & $\mathrm{AKRICl}$ & $\begin{array}{l}\text { aldo-keto reductase family } \\
\text { I, member } \mathrm{Cl} \text { (dihydrodiol } \\
\text { dehydrogenase I; } 20 \text {-alpha } \\
\text { (3-alpha)-hydroxysteroid } \\
\text { dehydrogenase) }\end{array}$ & 5.26 & 6.41 & 38.19 & 85.32 & & \\
\hline B-I:23-10 & NM_003914 & CCNAI & cyclin AI & 5.23 & 5.48 & 37.61 & 44.58 & & \\
\hline C-7:I-3 & NM_005986 & SOXI & $\begin{array}{l}\text { SRY (sex determining region } \\
\text { Y)-box I }\end{array}$ & 5.20 & 5.19 & 36.72 & 36.40 & & \\
\hline
\end{tabular}


TableContinued....

\begin{tabular}{|c|c|c|c|c|c|c|c|c|c|}
\hline \multirow{2}{*}{$\begin{array}{l}\text { Spot } \\
\text { Location }\end{array}$} & \multirow[b]{2}{*}{ UGRepAcc } & \multirow[b]{2}{*}{ Symbol } & \multirow[b]{2}{*}{ Name } & \multirow{2}{*}{$\begin{array}{l}\text { Clone } \\
\text { I I_log } \\
\text { ratio }\end{array}$} & \multirow{2}{*}{$\begin{array}{l}\text { Clone } \\
\text { I7_log } \\
\text { ratio }\end{array}$} & \multicolumn{2}{|l|}{ Up regulation } & \multicolumn{2}{|c|}{ Down regulation } \\
\hline & & & & & & $\begin{array}{l}\text { Foldchange } \\
\text { clonell }\end{array}$ & $\begin{array}{l}\text { Foldchange } \\
\text { clone } 17\end{array}$ & $\begin{array}{l}\text { Foldchange } \\
\text { clone I I }\end{array}$ & $\begin{array}{l}\text { Foldchange } \\
\text { clone } 17\end{array}$ \\
\hline D-5:15-6 & & & & 5.18 & 6.15 & 36.18 & 70.99 & & \\
\hline B-3:19-5 & NM_002422 & MMP3 & $\begin{array}{l}\text { matrix metalloproteinase } 3 \\
\text { (stromelysin I, progelatinase) }\end{array}$ & 5.04 & 5.65 & 33.01 & 50.37 & & \\
\hline D-5:18-3 & NM_181353 & IDI & $\begin{array}{l}\text { inhibitor of DNA binding I, } \\
\text { dominant negative helix-loop- } \\
\text { helix protein }\end{array}$ & 4.90 & 4.26 & 29.80 & 19.13 & & \\
\hline B-2:19-14 & NM_003I 25 & SPRRIB & $\begin{array}{l}\text { small proline-rich protein IB } \\
\text { (cornifin) }\end{array}$ & 4.61 & 2.79 & 24.46 & 6.94 & & \\
\hline C-I:18-14 & NM_0I7459 & MFAP2 & $\begin{array}{l}\text { microfibrillar-associated } \\
\text { protein } 2\end{array}$ & 4.57 & 13.81 & 23.77 & 14373.79 & & \\
\hline D-3:18-8 & NM_007366 & PLA2RI & $\begin{array}{l}\text { phospholipase } \mathrm{A} 2 \text { receptor } 1 \text {, } \\
180 \mathrm{kDa}\end{array}$ & 4.51 & 4.30 & 22.74 & 19.64 & & \\
\hline$D-6: 21-8$ & NM_000584 & IL8 & interleukin 8 & 4.42 & 2.03 & 21.34 & 4.08 & & \\
\hline$A-6: \mid 2-11$ & NM_00I978 & EPB49 & $\begin{array}{l}\text { erythrocyte membrane } \\
\text { protein band } 4.9 \text { (dematin) }\end{array}$ & 4.21 & 3.03 & 18.56 & 8.16 & & \\
\hline C-7:13-8 & NM_024829 & FLJ22662 & hypothetical protein FLJ22662 & 4.10 & 2.68 & 17.20 & 6.40 & & \\
\hline$C-3: 1-7$ & NM_|4579| & MGSTI & $\begin{array}{l}\text { microsomal glutathione } \\
\text { S-transferase I }\end{array}$ & 4.06 & 5.85 & 16.67 & 57.66 & & \\
\hline D-7:5-9 & NM_0I4656 & KIAA0040 & KIAA0040 gene product & 3.92 & 2.46 & 15.12 & 5.51 & & \\
\hline B-6:14-2 & NM_001964 & EGRI & early growth response I & 3.88 & 4.25 & 14.75 & 19.01 & & \\
\hline D-7:13-24 & NM_I44665 & SESN3 & sestrin 3 & 3.85 & 5.80 & $|4.4|$ & 55.80 & & \\
\hline$C-6: 14-23$ & AK00I903 & & $\begin{array}{l}\text { CDNA FLII I 04I fis, clone } \\
\text { PLACEI } 004405\end{array}$ & 3.77 & 4.94 & 13.67 & 30.61 & & \\
\hline B-I:15-6 & NM_002130 & HMGCSI & $\begin{array}{l}\text { 3-hydroxy-3-methylglutaryl- } \\
\text { Coenzyme A synthase I } \\
\text { (soluble) }\end{array}$ & 3.75 & 2.73 & 13.48 & 6.62 & & \\
\hline$C-4: 22-8$ & NM_006846 & SPINK5 & $\begin{array}{l}\text { serine protease inhibitor, } \\
\text { Kazal type, } 5\end{array}$ & 3.73 & 14.85 & 13.31 & 29489.80 & & \\
\hline C-1:22-9 & NM_002275 & KRTI5 & keratin 15 & 3.57 & 2.40 & 11.88 & 5.28 & & \\
\hline D-7:20-3 & NM_004473 & FOXEI & $\begin{array}{l}\text { forkhead box EI (thyroid } \\
\text { transcription factor 2) }\end{array}$ & 3.54 & 3.21 & 11.66 & 9.22 & & \\
\hline$D-3: 2-18$ & NM_032508 & FAMIIA & $\begin{array}{l}\text { family with sequence similarity } \\
\text { II, member } A\end{array}$ & 3.39 & 4.87 & 10.47 & 29.26 & & \\
\hline C-4:17-23 & AK026158 & LOC348938 & $\begin{array}{l}\text { hypothetical protein } \\
\text { LOC } 348938\end{array}$ & 3.37 & 4.67 & 10.37 & 25.42 & & \\
\hline B-5:5-I & NM_007286 & SYNPO & synaptopodin & 3.37 & 3.52 & 10.37 & 11.46 & & \\
\hline B-7:13-13 & NM_000299 & PKPI & $\begin{array}{l}\text { plakophilin I (ectodermal } \\
\text { dysplasia/skin fragility } \\
\text { syndrome) }\end{array}$ & 3.36 & 2.90 & 10.24 & 7.48 & & \\
\hline$C-5: 3-4$ & NM_00I452 & FOXF2 & forkhead box F2 & 3.35 & 2.70 & 10.22 & 6.50 & & \\
\hline D-7:16-23 & NM_03I455 & $\mathrm{CCDC} 3$ & $\begin{array}{l}\text { coiled-coil domain containing } \\
3\end{array}$ & 3.33 & 3.36 & 10.03 & 10.26 & & \\
\hline D-8:25-5 & NM_0I 2244 & SLC7A8 & $\begin{array}{l}\text { solute carrier family } \\
7 \text { (cationic amino acid } \\
\text { transporter, } y+\text { system), } \\
\text { member } 8\end{array}$ & 3.23 & 5.26 & 9.36 & 38.32 & & \\
\hline B-2:24-8 & NM_002996 & CX3CLI & $\begin{array}{l}\text { chemokine (C-X3-C motif) } \\
\text { ligand I }\end{array}$ & 3.22 & 6.33 & 9.29 & 80.62 & & \\
\hline
\end{tabular}


TableContinued....

\begin{tabular}{|c|c|c|c|c|c|c|c|c|c|}
\hline \multirow{2}{*}{$\begin{array}{l}\text { Spot } \\
\text { Location }\end{array}$} & \multirow[b]{2}{*}{ UGRepAcc } & \multirow[b]{2}{*}{ Symbol } & \multirow[b]{2}{*}{ Name } & \multirow{2}{*}{$\begin{array}{l}\text { Clone } \\
\text { I I_log } \\
\text { ratio }\end{array}$} & \multirow{2}{*}{$\begin{array}{l}\text { Clone } \\
\text { I7_log } \\
\text { ratio }\end{array}$} & \multicolumn{2}{|l|}{ Up regulation } & \multicolumn{2}{|c|}{ Down regulation } \\
\hline & & & & & & $\begin{array}{l}\text { Foldchange } \\
\text { clone I I }\end{array}$ & $\begin{array}{l}\text { Foldchange } \\
\text { clonel7 }\end{array}$ & $\begin{array}{l}\text { Foldchange } \\
\text { clone I I }\end{array}$ & $\begin{array}{l}\text { Foldchange } \\
\text { clone I } 7\end{array}$ \\
\hline B-6:6-19 & NM_004988 & MAGEAI & $\begin{array}{l}\text { melanoma antigen, family A, I } \\
\text { (directs expression of antigen } \\
\text { MZ2-E) }\end{array}$ & 3.13 & 4.28 & 8.74 & 19.45 & & \\
\hline D-7:24-I5 & NM_0I8950 & HLA-F & $\begin{array}{l}\text { major histocompatibility } \\
\text { complex, class I, F }\end{array}$ & 3.10 & 2.71 & 8.60 & 6.52 & & \\
\hline$D-2: 13-16$ & AF00I893 & & $\begin{array}{l}\text { MRNA; cDNA } \\
\text { DKFZp686L0II05 (from } \\
\text { clone DKFZp686L0II05) }\end{array}$ & 3.08 & 2.59 & 8.43 & 6.04 & & \\
\hline A-7:8-7 & NM_194298 & SLCI6A9 & $\begin{array}{l}\text { solute carrier family } 16 \\
\text { (monocarboxylic acid } \\
\text { transporters), member } 9\end{array}$ & 3.07 & 3.48 & 8.41 & 11.18 & & \\
\hline B-3:22-3 & NM_016307 & PRRX2 & paired related homeobox 2 & 3.05 & 2.72 & 8.26 & 6.57 & & \\
\hline$D-5: 11-12$ & NM_00I775 & CD38 & CD38 antigen ( $p 45)$ & 3.04 & 2.37 & 8.25 & 5.16 & & \\
\hline$C-8: 25-6$ & NM_00I360 & DHCR7 & $\begin{array}{l}\text { 7-dehydrocholesterol } \\
\text { reductase }\end{array}$ & 3.00 & 2.53 & 8.01 & 5.80 & & \\
\hline$D-5: 24-12$ & NM_005I30 & HBPI7 & $\begin{array}{l}\text { heparin-binding growth factor } \\
\text { binding protein }\end{array}$ & 3.00 & 2.25 & 8.00 & 4.77 & & \\
\hline$C-2: 11-23$ & BX640887 & & $\begin{array}{l}\text { CDNA clone IMAGE: } 3880075 \text {, } \\
\text { partial cds }\end{array}$ & 2.98 & 3.23 & 7.88 & 9.40 & & \\
\hline D-1:7-6 & NM_00I823 & CKB & creatine kinase, brain & 2.95 & 4.54 & 7.73 & 23.24 & & \\
\hline$D-4: 21-6$ & NM_002083 & GPX2 & $\begin{array}{l}\text { glutathione peroxidase } 2 \\
\text { (gastrointestinal) }\end{array}$ & 2.88 & 3.50 & 7.38 & 11.31 & & \\
\hline$B-6: 15-10$ & NM_006763 & BTG2 & BTG family, member 2 & 2.82 & 2.25 & 7.05 & 4.77 & & \\
\hline B-5:14-12 & NM_003028 & $\mathrm{SHB}$ & $\begin{array}{l}\text { SHB (Src homology } 2 \text { domain } \\
\text { containing) adaptor protein B }\end{array}$ & 2.80 & 16.66 & 6.97 & 103825.37 & & \\
\hline B-5:|7-1I & NM_004949 & DSC2 & desmocollin 2 & 2.78 & 2.04 & 6.86 & 4.12 & & \\
\hline$B-5:|9-1|$ & NM_002214 & ITGB8 & integrin, beta 8 & 2.73 & 3.22 & 6.65 & 9.32 & & \\
\hline C-7:19-9 & NM_000422 & KRTI7 & keratin 17 & 2.73 & 2.91 & 6.61 & 7.51 & & \\
\hline$A-5: 13-16$ & NM_000692 & ALDHIBI & $\begin{array}{l}\text { aldehyde dehydrogenase I } \\
\text { family, member BI }\end{array}$ & 2.61 & 2.33 & 6.12 & 5.03 & & \\
\hline$D-2: 12-17$ & NM_032333 & MGC4248 & $\begin{array}{l}\text { hypothetical protein } \\
\text { MGC4248 }\end{array}$ & 2.59 & 2.35 & 6.04 & 5.09 & & \\
\hline$A-1: 15-11$ & NM_00590I & $\mathrm{MADH} 2$ & $\begin{array}{l}\text { MAD, mothers against } \\
\text { decapentaplegic homolog } 2 \\
\text { (Drosophila) }\end{array}$ & 2.59 & 4.06 & 6.02 & 16.71 & & \\
\hline$D-8: 16-14$ & NM_000852 & GSTPI & glutathione S-transferase pi & 2.58 & 2.27 & 5.98 & 4.82 & & \\
\hline C-4:23-20 & AK000090 & & $\begin{array}{l}\text { CDNA FLJ20083 fis, clone } \\
\text { COL03440 }\end{array}$ & 2.55 & 2.84 & 5.85 & 7.14 & & \\
\hline C-4:24-20 & AK000794 & & $\begin{array}{l}\text { CDNA FLJ } 20787 \text { fis, clone } \\
\text { COL02178 }\end{array}$ & 2.46 & 3.16 & 5.51 & 8.95 & & \\
\hline$C-3: 18-14$ & NM_003480 & MAGP2 & $\begin{array}{l}\text { Microfibril-associated } \\
\text { glycoprotein-2 }\end{array}$ & 2.43 & 6.55 & 5.37 & 93.83 & & \\
\hline D-3:22-7 & NM_006822 & RAB40B & $\begin{array}{l}\text { RAB40B, member RAS } \\
\text { oncogene family }\end{array}$ & 2.39 & 2.64 & 5.25 & 6.22 & & \\
\hline B-5:16-8 & & & & 2.38 & 4.25 & 5.21 & 19.02 & & \\
\hline A-8:16-9 & NM_006096 & NDRGI & $\begin{array}{l}\mathrm{N} \text {-myc downstream regulated } \\
\text { gene I }\end{array}$ & 2.31 & 2.61 & 4.95 & 6.10 & & \\
\hline
\end{tabular}


TableContinued....

\begin{tabular}{|c|c|c|c|c|c|c|c|c|c|}
\hline \multirow{2}{*}{$\begin{array}{l}\text { Spot } \\
\text { Location }\end{array}$} & \multirow[b]{2}{*}{ UGRepAcc } & \multirow[b]{2}{*}{ Symbol } & \multirow[b]{2}{*}{ Name } & \multirow{2}{*}{$\begin{array}{l}\text { Clone } \\
\text { II_log } \\
\text { ratio }\end{array}$} & \multirow{2}{*}{$\begin{array}{l}\text { Clone } \\
\text { I7_log } \\
\text { ratio }\end{array}$} & \multicolumn{2}{|l|}{ Up regulation } & \multicolumn{2}{|c|}{ Down regulation } \\
\hline & & & & & & $\begin{array}{l}\text { Foldchange_ } \\
\text { clone I I }\end{array}$ & $\begin{array}{l}\text { Foldchange_ } \\
\text { clone I } 7\end{array}$ & $\begin{array}{l}\text { Foldchange } \\
\text { clone I I }\end{array}$ & $\begin{array}{l}\text { Foldchange } \\
\text { clonel } 7\end{array}$ \\
\hline$C-1: 12-10$ & NM_00443I & EPHA2 & EphA2 & 2.27 & 2.30 & 4.83 & 4.94 & & \\
\hline D-6:8-3 & NM_0I8555 & ZNF33I & zinc finger protein 331 & 2.27 & 3.64 & 4.81 & 12.44 & & \\
\hline B-7:19-6 & NM_0I4427 & CPNE7 & copine VII & 2.26 & 2.79 & 4.80 & 6.90 & & \\
\hline$C-2: 8-7$ & XM_370652 & $\mathrm{DNCH} 2$ & $\begin{array}{l}\text { dynein, cytoplasmic, heavy } \\
\text { polypeptide } 2\end{array}$ & 2.26 & 2.04 & 4.79 & 4.11 & & \\
\hline A-I:25-13 & NM_002820 & PTHLH & $\begin{array}{l}\text { parathyroid hormone-like } \\
\text { hormone }\end{array}$ & 2.26 & 3.14 & 4.78 & 8.82 & & \\
\hline C-4:|8-11 & NM_0I8I03 & LRRC5 & $\begin{array}{l}\text { leucine rich repeat containing } \\
5\end{array}$ & 2.23 & 3.37 & 4.70 & 10.32 & & \\
\hline A-8:13-I & & & & 2.21 & 2.60 & 4.62 & 6.07 & & \\
\hline D-7:21-1 & NM_000I04 & CYPIBI & $\begin{array}{l}\text { cytochrome P450, family I, } \\
\text { subfamily B, polypeptide I }\end{array}$ & 2.21 & 2.32 & 4.61 & 5.00 & & \\
\hline A-1:20-17 & NM_052932 & PORIMIN & $\begin{array}{l}\text { pro-oncosis receptor inducing } \\
\text { membrane injury gene }\end{array}$ & 2.18 & 2.04 & 4.53 & 4.12 & & \\
\hline$C-2: 1-3$ & NM_I3828I & DLX4 & distal-less homeobox 4 & 2.17 & 3.85 & 4.50 & $|4.4|$ & & \\
\hline$D-4: 19-17$ & AK024449 & PP2135 & PP2। 35 protein & 2.16 & 3.26 & 4.48 & 9.61 & & \\
\hline D-I:15-13 & NM_00I657 & AREG & $\begin{array}{l}\text { amphiregulin (schwannoma- } \\
\text { derived growth factor) }\end{array}$ & 2.16 & 2.43 & 4.47 & 5.37 & & \\
\hline D-I:13-2 & NM_005642 & TAF7 & $\begin{array}{l}\text { TAF7 RNA polymerase II, } \\
\text { TATA box binding protein } \\
\text { (TBP)-associated factor, } \\
55 \mathrm{kDa}\end{array}$ & 2.16 & 2.30 & 4.46 & 4.92 & & \\
\hline B-3:19-12 & NM_000597 & IGFBP2 & $\begin{array}{l}\text { insulin-like growth factor } \\
\text { binding protein } 2,36 \mathrm{kDa}\end{array}$ & 2.16 & 2.24 & 4.45 & 4.72 & & \\
\hline$C-1: 1-18$ & BQ43I04I & & $\begin{array}{l}\text { LOC388279 (LOC388279), } \\
\text { mRNA }\end{array}$ & 2.15 & 2.72 & 4.44 & 6.60 & & \\
\hline B-2:|7-2| & NM_007006 & CPSF5 & $\begin{array}{l}\text { cleavage and polyadenylation } \\
\text { specific factor } 5,25 \mathrm{kDa}\end{array}$ & 2.14 & 2.36 & 4.41 & 5.13 & & \\
\hline B-4:11-17 & NM_006096 & NDRGI & $\begin{array}{l}\text { N-myc downstream regulated } \\
\text { gene I }\end{array}$ & 2.14 & 2.39 & 4.41 & 5.24 & & \\
\hline$D-6: 15-7$ & & & & 2.09 & 2.05 & 4.24 & 4.15 & & \\
\hline A-I:17-3 & NM_0I6265 & ZNF325 & zinc finger protein 325 & 2.08 & 2.29 & 4.24 & 4.89 & & \\
\hline B-4:16-1I & NM_024423 & $\mathrm{DSC} 3$ & desmocollin 3 & 2.08 & 2.43 & 4.23 & 5.39 & & \\
\hline$C-4: 17-7$ & NM_006598 & SLCI2A7 & $\begin{array}{l}\text { solute carrier family } \\
\text { I2 (potassium/chloride } \\
\text { transporters), member } 7\end{array}$ & 2.03 & 2.62 & 4.08 & 6.13 & & \\
\hline$D-5: 8-6$ & NM_03I220 & PITPNM3 & PITPNM family member 3 & 2.01 & 2.94 & 4.02 & 7.70 & & \\
\hline A-7:1-16 & NM_0I57I4 & G0S2 & $\begin{array}{l}\text { putative lymphocyte G0/GI } \\
\text { switch gene }\end{array}$ & -2.02 & -2.59 & 0.25 & 0.17 & 4.067469826 & 6.02797569 \\
\hline D-4:7-17 & NM_000202 & IDS & $\begin{array}{l}\text { iduronate 2-sulfatase (Hunter } \\
\text { syndrome) }\end{array}$ & -2.03 & -2.75 & 0.25 & 0.15 & 4.077710921 & 6.75034936 \\
\hline D-3:6-9 & NM_000202 & IDS & $\begin{array}{l}\text { iduronate 2-sulfatase (Hunter } \\
\text { syndrome) }\end{array}$ & -2.04 & -2.87 & 0.24 & 0.14 & 4.101875487 & 7.29841054 \\
\hline$C-5: 25-16$ & NM_I38768 & MYEOV & $\begin{array}{l}\text { myeloma overexpressed } \\
\text { gene (in a subset of } \mathrm{t}(11 ; 14) \\
\text { positive multiple myelomas) }\end{array}$ & -2.05 & -2.49 & 0.24 & 0.18 & 4.144497434 & 5.62253016 \\
\hline
\end{tabular}


TableContinued...

\begin{tabular}{|c|c|c|c|c|c|c|c|c|c|}
\hline \multirow{2}{*}{$\begin{array}{l}\text { Spot } \\
\text { Location }\end{array}$} & \multirow[b]{2}{*}{ UGRepAcc } & \multirow[b]{2}{*}{ Symbol } & \multirow[b]{2}{*}{ Name } & \multirow{2}{*}{$\begin{array}{l}\text { Clone } \\
\text { II_log } \\
\text { ratio }\end{array}$} & \multirow{2}{*}{$\begin{array}{l}\text { Clone } \\
\text { I7_log } \\
\text { ratio }\end{array}$} & \multicolumn{2}{|l|}{ Up regulation } & \multicolumn{2}{|c|}{ Down regulation } \\
\hline & & & & & & $\begin{array}{l}\text { Foldchange } \\
\text { clone I I }\end{array}$ & $\begin{array}{l}\text { Foldchange } \\
\text { clone } 17\end{array}$ & $\begin{array}{l}\text { Foldchange } \\
\text { clone I I }\end{array}$ & $\begin{array}{l}\text { Foldchange } \\
\text { clonel } 7\end{array}$ \\
\hline D-3:23-9 & NM_018222 & PARVA & parvin, alpha & -2.05 & -2.56 & 0.24 & 0.17 & 4.145801706 & 5.88473227 \\
\hline B-7:4-23 & NM_I82507 & LOCI4450I & $\begin{array}{l}\text { hypothetical protein } \\
\text { LOCI } 4450 \text { I }\end{array}$ & -2.07 & -4.11 & 0.24 & 0.06 & 4.208758818 & 17.3227835 \\
\hline C-8:22-13 & NM_020799 & AMSH-LP & $\begin{array}{l}\text { associated molecule with the } \\
\text { SH3 domain of STAM (AMSH) } \\
\text { like protein }\end{array}$ & -2.08 & -2.34 & 0.24 & 0.20 & 4.214203909 & 5.04987403 \\
\hline A-5: $10-10$ & NM_003087 & SNCG & $\begin{array}{l}\text { synuclein, gamma (breast } \\
\text { cancer-specific protein I) }\end{array}$ & -2.11 & -2.18 & 0.23 & 0.22 & 4.30472467 & 4.53020489 \\
\hline D-7:I2-I & NM_014297 & ETHEI & ethylmalonic encephalopathy I & -2.14 & -2.15 & 0.23 & 0.23 & 4.419559792 & 4.43492191 \\
\hline D-3:16-8 & NM_000963 & PTGS2 & $\begin{array}{l}\text { prostaglandin-endoperoxide } \\
\text { synthase } 2 \text { (prostaglandin } \mathrm{G} / \mathrm{H} \\
\text { synthase and cyclooxygenase) }\end{array}$ & -2.18 & -2.20 & 0.22 & 0.22 & 4.533257978 & 4.60992803 \\
\hline C-8:I-10 & NM_02248I & ARAP3 & $\begin{array}{l}\text { ARF-GAP, RHO-GAP, } \\
\text { ankyrin repeat and plekstrin } \\
\text { homology domains-containing } \\
\text { protein } 3\end{array}$ & -2.18 & -2.59 & 0.22 & 0.17 & 4.542590739 & 6.02919293 \\
\hline C-7:5-7 & NM_023927 & NS3TP2 & $\begin{array}{l}\text { HCV NS3-transactivated } \\
\text { protein } 2\end{array}$ & -2.19 & -3.26 & 0.22 & 0.10 & 4.566722537 & $9.58576 \mid 43$ \\
\hline$D-5: 12-13$ & NM_000024 & ADRB2 & $\begin{array}{l}\text { adrenergic, beta-2-, receptor, } \\
\text { surface }\end{array}$ & -2.22 & -2.05 & 0.21 & 0.24 & 4.674568202 & 4.13068734 \\
\hline$D-4: 19-2$ & NM_03I283 & TCF7LI & $\begin{array}{l}\text { transcription factor 7-like I } \\
\text { (T-cell specific, HMG-box) }\end{array}$ & -2.25 & -3.09 & 0.21 & 0.12 & 4.77061901 & $8.52709 \mid 49$ \\
\hline B-7:5-9 & NM_000916 & OXTR & oxytocin receptor & -2.29 & -2.33 & 0.20 & 0.20 & 4.890803849 & 5.0310331 \\
\hline A-7:6-15 & NM_003289 & TPM2 & tropomyosin 2 (beta) & -2.32 & -2.76 & 0.20 & 0.15 & $5.00854 \mid 393$ & 6.78462145 \\
\hline B-2:12-7 & NM_0I5994 & ATP6VID & $\begin{array}{l}\text { ATPase, } \mathrm{H}+\text { transporting, } \\
\text { lysosomal } 34 \mathrm{kDa}, \mathrm{VI} \text { subunit } \\
\text { D }\end{array}$ & -2.33 & -2.16 & 0.20 & 0.22 & 5.025197605 & 4.46298352 \\
\hline D-3:|8-II & NM_000610 & CD44 & $\begin{array}{l}\text { CD44 antigen (homing } \\
\text { function and Indian blood } \\
\text { group system) }\end{array}$ & -2.34 & -2.76 & 0.20 & 0.15 & 5.056402704 & 6.77232189 \\
\hline$C-3: 12-5$ & NM_0I4256 & B3GNT3 & $\begin{array}{l}\text { UDP-GlcNAc:betaGal } \\
\text { beta-I,3-N- } \\
\text { acetylglucosaminyltransferase } \\
3\end{array}$ & -2.35 & -2.53 & 0.20 & 0.17 & 5.084537435 & 5.7804644 \\
\hline A-5:3-14 & NM_005096 & ZNF26I & zinc finger protein $26 \mathrm{I}$ & -2.39 & -2.39 & 0.19 & 0.19 & 5.248917876 & 5.25675946 \\
\hline B-4:10-12 & & & & -2.41 & -2.29 & 0.19 & 0.20 & 5.306823008 & 4.88133901 \\
\hline A-5:16-14 & NM_000224 & KRTI8 & keratin 18 & -2.43 & -2.36 & 0.19 & 0.19 & 5.404795682 & 5.14281952 \\
\hline B-7:8-16 & NM_005780 & LHFP & lipoma HMGIC fusion partner & -2.47 & -2.68 & 0.18 & 0.16 & 5.538633731 & 6.4003583 \\
\hline$C-3: 5-6$ & NM_080927 & ESDN & $\begin{array}{l}\text { endothelial and smooth } \\
\text { muscle cell-derived } \\
\text { neuropilin-like protein }\end{array}$ & -2.47 & -2.22 & 0.18 & 0.21 & 5.549855877 & 4.65363937 \\
\hline B-6:14-9 & NM_000224 & KRTI8 & keratin 18 & -2.49 & -3.07 & 0.18 & 0.12 & 5.620597234 & 8.37846833 \\
\hline
\end{tabular}


TableContinued...

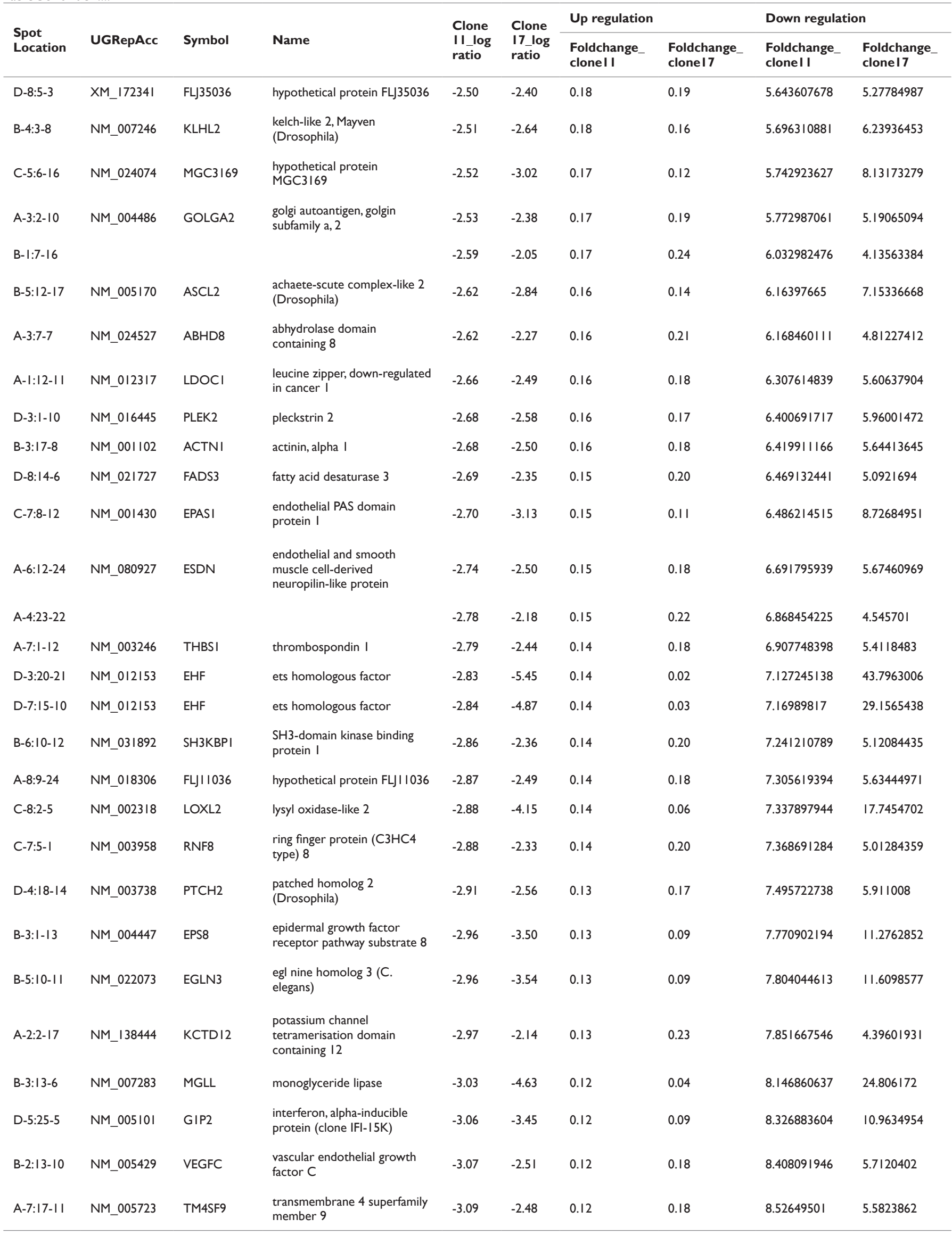


TableContinued...

\begin{tabular}{|c|c|c|c|c|c|c|c|c|c|}
\hline \multirow{2}{*}{$\begin{array}{l}\text { Spot } \\
\text { Location }\end{array}$} & \multirow[b]{2}{*}{ UGRepAcc } & \multirow[b]{2}{*}{ Symbol } & \multirow[b]{2}{*}{ Name } & \multirow{2}{*}{$\begin{array}{l}\text { Clone } \\
\text { I I_log } \\
\text { ratio }\end{array}$} & \multirow{2}{*}{$\begin{array}{l}\text { Clone } \\
17 \text { log } \\
\text { ratio }\end{array}$} & \multicolumn{2}{|l|}{ Up regulation } & \multicolumn{2}{|c|}{ Down regulation } \\
\hline & & & & & & $\begin{array}{l}\text { Foldchange } \\
\text { clone I I }\end{array}$ & $\begin{array}{l}\text { Foldchange } \\
\text { clone } 17\end{array}$ & $\begin{array}{l}\text { Foldchange } \\
\text { clone I I }\end{array}$ & $\begin{array}{l}\text { Foldchange } \\
\text { clone I } 7\end{array}$ \\
\hline$A-4: 12-17$ & NM_I536II & MGC20446 & $\begin{array}{l}\text { hypothetical protein } \\
\text { MGC20446 }\end{array}$ & -3.09 & -3.06 & 0.12 & 0.12 & 8.539562097 & 8.34144982 \\
\hline A-8:7-II & NM_018192 & MLAT4 & $\begin{array}{l}\text { myxoid liposarcoma } \\
\text { associated protein } 4\end{array}$ & -3.17 & -3.31 & 0.11 & 0.10 & 8.979387807 & 9.94098854 \\
\hline$A-5: 14-13$ & NM_057I59 & EDG2 & $\begin{array}{l}\text { endothelial differentiation, } \\
\text { lysophosphatidic acid } \\
\text { G-protein-coupled receptor, } 2\end{array}$ & -3.18 & -3.02 & 0.11 & 0.12 & 9.055761789 & 8.11254773 \\
\hline D-8:14-5 & NM_004995 & MMPI4 & $\begin{array}{l}\text { matrix metalloproteinase } 14 \\
\text { (membrane-inserted) }\end{array}$ & -3.19 & -2.47 & 0.11 & 0.18 & 9.124402264 & 5.54910849 \\
\hline A-3:24-10 & NM_00I553 & IGFBP7 & $\begin{array}{l}\text { insulin-like growth factor } \\
\text { binding protein } 7\end{array}$ & -3.20 & -2.47 & 0.11 & 0.18 & 9.194347608 & 5.52503874 \\
\hline$A-5: 6-16$ & NM_003803 & MYOMI & $\begin{array}{l}\text { myomesin I (skelemin) } \\
\text { I85kDa }\end{array}$ & -3.29 & -3.91 & 0.10 & 0.07 & 9.774320104 & 15.0783315 \\
\hline$C-2: 5-5$ & NM_0I6233 & PADI3 & $\begin{array}{l}\text { peptidyl arginine deiminase, } \\
\text { type III }\end{array}$ & -3.30 & -4.77 & 0.10 & 0.04 & 9.862444313 & 27.3226366 \\
\hline A-8:24-7 & NM_006517 & $\mathrm{SLCl6A2}$ & $\begin{array}{l}\text { solute carrier family } 16 \\
\text { (monocarboxylic acid } \\
\text { transporters), member } 2 \\
\text { (putative transporter) }\end{array}$ & -3.37 & -3.57 & 0.10 & 0.08 & $|0.3488283|$ & 11.8464534 \\
\hline$C-6: 15-6$ & NM_0I2I05 & BACE2 & $\begin{array}{l}\text { beta-site APP-cleaving enzyme } \\
2\end{array}$ & -3.38 & -2.18 & 0.10 & 0.22 & 10.43754205 & 4.54496723 \\
\hline$A-6: 13-6$ & NM_005672 & PSCA & prostate stem cell antigen & -3.39 & -3.50 & 0.10 & 0.09 & 10.47451419 & 11.2751577 \\
\hline$A-3: 8-16$ & NM_002273 & KRT8 & keratin 8 & -3.45 & -3.79 & 0.09 & 0.07 & $|0.9576055|$ & 13.8757902 \\
\hline$C-8: 4-16$ & NM_007085 & FSTLI & follistatin-like I & -3.47 & -6.65 & 0.09 & 0.01 & 11.11533316 & 100.251904 \\
\hline C-6:17-7 & NM_004207 & $\mathrm{SLCI}$ 6A3 & $\begin{array}{l}\text { solute carrier family } 16 \\
\text { (monocarboxylic acid } \\
\text { transporters), member } 3\end{array}$ & -3.51 & -3.98 & 0.09 & 0.06 & 11.36560673 & 15.793495 \\
\hline C-4:6-1I & NM_007203 & PALM2 & paralemmin 2 & -3.51 & -2.13 & 0.09 & 0.23 & II.4246333 & 4.36597548 \\
\hline D-5:19-4 & & & & -3.57 & -2.78 & 0.08 & 0.15 & II.85742483 & 6.8516617 \\
\hline$A-3: 15-9$ & NM_000295 & SERPINAI & $\begin{array}{l}\text { serine (or cysteine) } \\
\text { proteinase inhibitor, clade } \\
\text { A (alpha-I antiproteinase, } \\
\text { antitrypsin), member I }\end{array}$ & -3.61 & -6.57 & 0.08 & 0.01 & $|2.2099||4|$ & 95.0583386 \\
\hline A-I:I-15 & NM_003II8 & SPARC & $\begin{array}{l}\text { secreted protein, acidic, } \\
\text { cysteine-rich (osteonectin) }\end{array}$ & -3.61 & -3.10 & 0.08 & 0.12 & 12.24073208 & $8.5780|88|$ \\
\hline A-4:15-9 & & & & -3.65 & -2.44 & 0.08 & 0.18 & $12.56 \mid 72657$ & 5.44344481 \\
\hline A-3:4-14 & NM_00I654 & TIMPI & $\begin{array}{l}\text { tissue inhibitor of } \\
\text { metalloproteinase I } \\
\text { (erythroid potentiating } \\
\text { activity, collagenase inhibitor) }\end{array}$ & -3.71 & -3.05 & 0.08 & 0.12 & 13.12721004 & 8.26900241 \\
\hline A-4:20-I & & & & -3.95 & -2.89 & 0.06 & 0.14 & 15.49965719 & 7.39869191 \\
\hline D-7:8-6 & NM_021005 & NR2F2 & $\begin{array}{l}\text { nuclear receptor subfamily } 2 \text {, } \\
\text { group F, member } 2\end{array}$ & -3.98 & -3.54 & 0.06 & 0.09 & $15.74627 \mid 36$ & 11.6231813 \\
\hline B-4:12-5 & NM_00II 09 & ADAM8 & $\begin{array}{l}\text { a disintegrin and } \\
\text { metalloproteinase domain } 8\end{array}$ & -4.26 & -4.02 & 0.05 & 0.06 & 19.10086542 & 16.2296299 \\
\hline D-8:|7-1। & NM_00I792 & $\mathrm{CDH} 2$ & $\begin{array}{l}\text { cadherin 2, type I, N-cadherin } \\
\text { (neuronal) }\end{array}$ & -4.36 & -2.91 & 0.05 & 0.13 & 20.529152 & 7.52090111 \\
\hline A-6:2-10 & NM_182909 & $\mathrm{DOCl}$ & $\begin{array}{l}\text { downregulated in ovarian } \\
\text { cancer I }\end{array}$ & -4.39 & -2.59 & 0.05 & 0.17 & 20.95746529 & 6.00852077 \\
\hline
\end{tabular}


TableContinued...

\begin{tabular}{|c|c|c|c|c|c|c|c|c|c|}
\hline \multirow{2}{*}{$\begin{array}{l}\text { Spot } \\
\text { Location }\end{array}$} & \multirow[b]{2}{*}{ UGRepAcc } & \multirow[b]{2}{*}{ Symbol } & \multirow[b]{2}{*}{ Name } & \multirow{2}{*}{$\begin{array}{l}\text { Clone } \\
\text { II_log } \\
\text { ratio }\end{array}$} & \multirow{2}{*}{$\begin{array}{l}\text { Clone } \\
\text { I7_log } \\
\text { ratio }\end{array}$} & \multicolumn{2}{|l|}{ Up regulation } & \multicolumn{2}{|c|}{ Down regulation } \\
\hline & & & & & & $\begin{array}{l}\text { Foldchange } \\
\text { clone II }\end{array}$ & $\begin{array}{l}\text { Foldchange } \\
\text { clone I } 7\end{array}$ & $\begin{array}{l}\text { Foldchange } \\
\text { clonel I }\end{array}$ & $\begin{array}{l}\text { Foldchange } \\
\text { clone } 17\end{array}$ \\
\hline B-7:24-6 & NM_0245I9 & FLJI 3725 & hypothetical protein FLJI3725 & -4.46 & -3.29 & 0.05 & 0.10 & 21.95627756 & 9.77013135 \\
\hline$D-2:|0-1|$ & NM_005727 & TSPAN-I & tetraspan I & -4.47 & -6.29 & 0.05 & 0.01 & 22.16640231 & $78.123977 \mid$ \\
\hline$D-5: 8-10$ & & & & -4.72 & -4.91 & 0.04 & 0.03 & $26.3 \mid 474624$ & 29.984916 \\
\hline C-7:6-9 & NM_00033I & SAAI & serum amyloid AI & -5.15 & -2.41 & 0.03 & 0.19 & 35.45660337 & 5.32381919 \\
\hline$D-4: 14-14$ & NM_0I 2427 & KLK5 & kallikrein 5 & -5.30 & -6.55 & 0.03 & 0.01 & 39.43541733 & 93.616596 \\
\hline B-8:2I-1I & AF200348 & D2S448 & Melanoma associated gene & -6.08 & -5.15 & 0.01 & 0.03 & 67.5205415 & 35.4459189 \\
\hline D-2:7-14 & NM_00I323 & CST6 & cystatin $E / M$ & -6.35 & -6.34 & 0.01 & 0.01 & 81.42425084 & 81.0151155 \\
\hline
\end{tabular}

Table 2 Common genes that are differentially regulated between OSC19LEKTI clone II in comparison with the OSCI9-Vector clone I.The negative fold change values are for genes that are down regulated and the positive fold change values are genes that are up regulated in the clone

\begin{tabular}{ll}
\hline Gene name & Fold change \\
\hline MMP-14 & -9.2 \\
MMP-8 & -19.5 \\
KLK5 & -93.6 \\
ADAM8 & -16.5 \\
MMP3 & +14.9 \\
LEKTI & +80.8 \\
DSC2 & +10.8 \\
DSC3 & +5.8 \\
\hline
\end{tabular}

Using LEKTI mAb 1C11G6, we observed that in specimens of histologically normal mucosa, LEKTI-positive staining was present in the cytoplasm of epithelial cells extending above the basal layers. Conversely, in specimens of dysplastic mucosa, LEKTI-positive staining was diminished in all layers of the epithelium. Moreover, in the majority of specimens of invasive carcinoma staining was limited to a few cells scattered within the tumor of nests of more differentiated tumor cells. Our immunohistochemical analysis of LEKTI expression in matched HNSCC patient specimens confirmed our previous findings of lost or down-regulated LEKTI mRNA transcription in similar specimens (16). We also plan to determine the expression status of severalmMP-9, mMP-14, mMP-3, and KLK5 in HNSCC tumor specimens to expand the relevance of our cell culture-based findings to patient derived tissues.

\section{Conclusion}

The enhancement of adhesion to ECM constituents along with the alteration in expression pattern of mMPs in LEKTI expressing clones of OSC19 demonstrates a mechanism of impaired invasive capacity. Our findings define a novel role in which LEKTI provides a critical cellular switch from stationary to migratory cell phases.

\section{Acknowledgements}

Supported in part by the NIH-NCI P50 CA097007, NIH R01 DE013954, NIH P30 CA016672, Alando J Ballantyne Distinguished Chair in Head and Neck Surgery award, Michael A. O'Bannon Endowment for Cancer Research, NIH INRS Award T32 CA060374, and AAO-HNSF Percy Memorial Grant.

\section{Conflict of interest}

The author declares no conflict of interest.

\section{References}

1. Magert HJ, Standker L, Kreutzmann P, et al. LEKTI, a novel 15domain type of human serine proteinase inhibitor. $J$ Biol Chem. 1999;274(31):21499-214502.

2. Chavanas S, Bodemer C, Rochat A, et al. Mutations in SPINK5, encoding a serine protease inhibitor, cause Netherton syndrome. Nat Genet. 2000;25(2):141-142.

3. Muller FB, Hausser I, Berg D, et al. Genetic analysis of a severe case of Netherton syndrome and application for prenatal testing. Br J Dermatol. 2002;146(3):495-499.

4. Bitoun E, Bodemer C, Amiel J, et al. Prenatal diagnosis of a lethal form of Netherton syndrome by SPINK5 mutation analysis. Prenat Diagn. 2002;22(2):121-126.

5. Komatsu N, Takata M, Otsuki N, et al. Elevated stratum corneum hydrolytic activity in Netherton syndrome suggests an inhibitory regulation of desquamation by SPINK5-derived peptides. J Invest Dermatol. 2002;118(3):436-443.

6. Bitoun E, Chavanas S, Irvine AD, et al. Netherton syndrome: disease expression and spectrum of SPINK5 mutations in 21 families. $J$ Invest Dermatol. 2002;118(2):352-361.

7. Stoll C, Alembik Y, Tchomakov D, et al. Severe hypernatremic dehydration in an infant with Netherton syndrome. Genet Couns. 2001;12(3):237-243.

8. Sprecher E, Chavanas S, DiGiovanna JJ, et al. The spectrum of pathogenic mutations in SPINK5 in 19 families with Netherton syndrome:implications for mutation detection and first case of prenatal diagnosis. J Invest Dermatol. 2001;117(2):179-187.

9. Descargues P, Deraison C, Bonnart C, et al. Spink5-deficient mice mimic Netherton syndrome through degradation of desmoglein 1 by epidermal protease hyperactivity. Nat Genet. 2005;37(1):56-65.

10. Komatsu N, Saijoh K, Jayakumar A, et al. Correlation between SPINK5 gene mutations and clinical manifestations in Netherton syndrome patients. J Invest Dermatol. 2008;128(5):1148-1159.

11. Di WL, Hennekam RC, Callard RE, et al. A heterozygous null mutation combined with the G1258A polymorphism of SPINK5 causes impaired LEKTI function and abnormal expression of skin barrier proteins. $\mathrm{Br} J$ Dermatol. 2009;161(2):404-412.

12. Diociaiuti A, Castiglia D, Fortugno P, et al. Lethal Netherton syndrome due to homozygous p.Arg371X mutation in SPINK5. Pediatr Dermatol. 2013;30(4):e65-e67. 
13. D'Alessio M, Fortugno P, Zambruno G, et al. Netherton syndrome and its multifaceted defective protein LEKTI. G Ital Dermatol Venereol. 2013;148(1):37-51.

14. Walden M, Kreutzmann P, Drogemuller K, et al. Biochemical features, molecular biology and clinical relevance of the human 15-domain serine proteinase inhibitor LEKTI. Biol Chem. 2002;383(7-8):1139-1141.

15. Lauber T, Schulz A, Schweimer K, et al. Homologous proteins with different folds:the three-dimensional structures of domains 1 and 6 of the multiple Kazal-type inhibitor LEKTI. J Mol Biol. 2003;328(1):205-219.

16. Gonzalez HE, Gujrati M, Frederick M, et al. Identification of 9 genes differentially expressed in head and neck squamous cell carcinoma. Arch Otolaryngol Head Neck Surg. 2003;129(7):754-759.

17. Shah TM, Patel AK, Bhatt VD, et al. The landscape of alternative splicing in buccal mucosa squamous cell carcinoma. Oral Oncol. 2013;49(6):604-610

18. Mitsudo K, Jayakumar A, Henderson Y, et al. Inhibition of serine proteinases plasmin, trypsin, subtilisin A, cathepsin $\mathrm{G}$, and elastase by LEKTI: a kinetic analysis. Biochemistry. 2003;42(13):3874-3881.

19. Jayakumar A, Kang Y, Mitsudo K, et al. Expression of LEKTI domains 6-9' in the baculovirus expression system:recombinant LEKTI domains 6-9' inhibit trypsin and subtilisin A. Protein Expr \& Purif. 2004;35(1):93-101.

20. Raghunath M, Tontsidou L, Oji V, et al. SPINK5 and Netherton syndrome: novel mutations, demonstration of missing LEKTI, and differentia expression of transglutaminases. J Invest Dermatol. 2004;123(3):474483.

21. Jayakumar A, Kang Y, Henderson Y, et al. Consequences of Cterminal domains and $\mathrm{N}$-terminal signal peptide deletions on LEKTI secretion, stability, and subcellular distribution. Arch Biochem Biophys. 2005;435(1):89-102.

22. Schechter NM, Choi EJ, Wang ZM, et al. Inhibition of human kallikreins 5 and 7 by the serine protease inhibitor lympho-epithelial Kazal-type inhibitor (LEKTI). Biol Chem. 2005;386(11):1173-1184.
23. Deraison C, Bonnart C, Lopez F, et al. LEKTI fragments specifically inhibit KLK5, KLK7, and KLK14 and control desquamation through a pH-dependent interaction. Mol Biol Cell. 2007;18(9):3607-3619.

24. Borgono CA, Michael IP, Komatsu N, et al. A potential role for multiple tissue kallikrein serine proteases in epidermal desquamation. $J$ Biol Chem. 2007;282(6):3640-3652.

25. Hachem JP, Wagberg F, Schmuth M, et al. Serine protease activity and residual LEKTI expression determine phenotype in Netherton syndrome. J Invest Dermatol. 2006;126(7):1609-1621.

26. Bennett K, Callard R, Heywood W, et al. New role for LEKTI in skin barrier formation: label-free quantitative proteomic identification of caspase 14 as a novel target for the protease inhibitor LEKTI. J Proteome Res. 2010;9(8):4289-4294.

27. Jayakumar A, Huang WY, Raetz B, et al. Cloning and expression of the multifunctional human fatty acid synthase and its subdomains in Escherichia coli. Proc Natl Acad Sci U S A. 1996;93(25):14509-14514.

28. Henderson YC, Frederick MJ, Jayakumar A, et al. Human LBP-32/MGR is a repressor of the P450scc in human choriocarcinoma cell line JEG-3. Placenta. 2007;28(2-3):152-160.

29. Klopp AH, Jhingran A, Ramdas L, et al. Gene expression changes in cervical squamous cell carcinoma after initiation of chemoradiation and correlation with clinical outcome. Int $J$ Radiat Oncol Biol Phys. 2008;71(1):226-236

30. Bitoun E, Micheloni A, Lamant L, et al. LEKTI proteolytic processing in human primary keratinocytes, tissue distribution and defective expression in Netherton syndrome. Hum Mol Genet. 2003;12(19):2417-2430.

31. Jayakumar A, Cataltepe S, Kang Y, et al. Production of serpins using baculovirus expression systems. Methods. 2004;32:177-184.

32. Roomi MW, Kalinovsky T, Rath M, et al. Modulation of u-PA, MMPs and their inhibitors by a novel nutrient mixture in human female cancer cell lines. Oncol Rep. 2012;28(3):768-776.

33. Woessner JF Jr. MMPs and TIMPs - an historical perspective. Mol Biotechnol. 2002;22(1):33-49. 